\title{
ADMINISTRATIVE PROCESS REFORM IN A DISCRETIONARY AGE: THE ROLE OF SOCIAL CONSEQUENCES
}

\author{
Wesley A. Magat* \\ AND ChRISTOPHER $\mathrm{H}$. SCHROEDER**
}

The basic rulemaking procedures of the Administrative Procedure Act have remained intact for thirty-eight years, but now Congress is seriously considering reform of those generic rules. To evaluate the merits of these reform proposals, we must develop criteria against which to judge them. Although procedural reforms are commonly judged against the goals of fairness, accuracy, and procedural efficiency, Professors Schroeder and Magat argue that these are insufficient criteria to apply to administrative process reforms at a time when agencies possess substantial discretion in the rulemaking process. In such a context, procedures have an impact on society in ways not adequately evaluated by the traditional criteria. Discretion means that agencies may choose from a set of possible rules, none of which has been foreclosed by the enabling legislation of the agency. Procedures influence which choices the agency makes and, because these choices alter the regulations and restrictions under which society operates, they affect the social consequences of regulation. This article describes a model of participant behavior necessary to trace the effects of procedures on the social consequences of regulation, articulates a set of criteria to evaluate these social consequences, and then analyzes two frequently proposed generic reforms to the APA: mandatory regulatory impact analysis and oversight by the Office of Management and Budget.

\section{INTRODUCTION}

Last term, in Immigration \& Naturalization Service v. Chadha, ${ }_{1}^{1}$ the Supreme Court held unconstitutional the legislative veto, a fifty year old practice in which Congress retained authority to review and cancel certain executive actions without presidential approval and, in some cases, without the approval of both houses. In a rare, exteinporaneous oral dissent, Justice White attacked the decision. In his formal written opinion, Justice White defended the legislative veto as "an important if not indispensable political invention that allows the President and Business.

- Associate Professor of Business Administration, Duke University, Fuqua School of

** Associate Professor of Law, Duke University.

1. 103 S. Ct. 2764,2788 (1983). 
Congress to resolve major constitutional and policy differences, assures the accountability of independent regulatory agencies, and preserves Congress' control over lawmaking."2 Immediately following the decision, press and congressional attention focused on the ruling's dramatic shift of power away from Congress and toward a remvigorated, imperial Presidency, especially in matters of foreign affairs and the budget. ${ }^{3}$

Chadha's repercussions on domestic regulatory matters, however, nay be just as important as those on congressional-presidential power relationships in matters of foreign affairs and the budget. Before the Court's decision, Congress had employed veto provisions designed to give itself leverage over the rulemaking decisions of a number of federal agencies. 4 Whatever the merits of its specific uses, this veto authority was a legislative response to the problem of controlling administrative discretion - a problem heightened by the growth of federal agency influence on the daily affairs of private citizens. Although the Supreme Court eliminated this device for controlling discretion, the publicity surrounding the decision may move the problem of controlling agency discretion to the foreground of public concern.

Congress, the courts, and critics of the new regulatory state have wrestled with this problem for some time, and no single, unified critique or reform strategy has yet evolved because the issues involved are complicated and perceptions of their precise nature vary. Nevertheless, a consensus in Congress appears to have concluded that certain administrative rulemaking procedural reforms could ensure fairer, more accurate, and more sensible regulations. These changes would ainend the basic rulemaking structure of the seminal Administrative Procedure Act (APA) for the first time smce it was enacted thirty-eight years ago. ${ }^{5}$

This article presents a framework for analyzing the merits of administrative procedural reforms. Its premise is that procedural reforms must be analyzed on a broader basis than the traditional inquirywhether they will improve the internal workings of agencies by ensuring accurate fact finding, fair opportunity for public imput, and consistency with statutory mandates. The wider social impact of procedural

2. Id. at 2795 (White, J., dissenting).

3. See, e.g., Wash. Post, June 24, 1983, at A4, col. 4-6. Among the foreign affairs statutes affected by Chadha were the veto provisions in the War Powers Resolution, $\S 5$, 50 U.S.C. $\S 1544$ (1976 and Supp. V 1981), and The Arms Export Control Act, § 211, 22 U.S.C. § 2776(b) (1982); on the budget side, statutes with veto provisions include the Congressional Budget and lmpoundment Control Act of 1974, § 1013, 31 U.S.C. $\$ 1403$ (1976). Justice White's dissent in Chadha contains a long list of legislation containing veto provisions. See $103 \mathrm{~S}$. Ct. at 2811-16 (White, J., dissenting).

4. See 103 S. Ct. 2764, 2811-16 (White, J., dissenting)(appendix of statutes with provisions authorizing congressional review).

5. Administrative Procedure Act, Pub. L. No. 79-404, 60 Stat. 237 (1946). 
reforms must also be assessed. New procedures tend to lead to different agency decisions, which in turn lead to different social consequences. Predicting these new social consequences-no simple task-is a prerequisite to appraising the merits of suggested reforms. If Chadha turns Congress's attention to alternative procedural reforms, such an appraisal takes on immediate importance.

Part II of this article briefly charts the growth of the administrative state, and relates procedural reform to other reform proposals. Part III argues that the substantial administrative discretion that agencies possess compels an analysis of the social consequences of process reform proposals. Part IV distinguishes an "internal view" of process froin our "social consequences" view and argues that the former is incoinplete in an adıninistrative climate containing such discretion. Part V illustrates how the social consequences of procedural change can be anticipated with a simple inodel of participant behavior. Part VI specifies six criteria for evaluating the consequences of procedural change, and Part VII applies the inodel and these criteria to two frequently proposed annendments to the APA's generic rulemaking provisions. The article concludes with some speculation on the prospects for meaningful reform of the regulatory process.

\section{The APA, The Regulatory State, and Reform Proposals}

The Administrative Procedure Act of $1946^{6}$ was liailed as "a new, basic and comprehensive regulation of procedures"' for federal administrative agencies. It was a singular achievement that balanced efficient and effective management of government business with respect for the rights of individuals. By 1946, government administration was already extraordimarily complex. ${ }^{8}$ Congress's enactment of the APA ended a search for procedural controls on bureaucratic affairs that would both treat regulated parties fairly and permit the flexibility Congress thought necessary to ensure sound management of admimistrative agency tasks. It is a tribute to the diligent work that preceded the Act and the foresight that accompanied its passage that the APA has remained essentially intact, despite significant changes in the volume and nature of

6. 5 U.S.C. $\$ \S 553-559,701-706$ (1982).

7. Wong Yang Sung v. McGrath, 339 U.S. 33, 36 (1950).

8. In recommending the APA, the Attorney General's Committee on Administrative Procedure emphasized the importance of retaining flexibility in administrative procedure to accommodate the wide array of functions agencies had been directed to perform. ATTORNEY GENERAL'S Committee on Administrative Procedure, Final Report 34-42 (1941). 
federal agency activities and in the public's perception of the values that must be served when agencies regulate.?

Although the APA has remained intact, administrative agencies have operated under a "recurrent sense of crisis" fueled by criticisms of their work. ${ }^{10}$ Until recently, however, none of this criticism has been aimed directly at the heart of the APA's basic structure and design. Instead, the critics claimed that the agencies had faulty structure and organization. They recominended that single-head agencies replace multiple-member commissions or that agency officials be directly responsible to the President rather than able to act semiautonomously. ${ }^{11}$ Others sought either deregulation or nore specific statutory standards. ${ }^{12}$ These charges and reforms can be accommodated without changing the APA's underlying procedural guidelines; to answer such complaints, Congress need only adjust a particular agency's structure or the organic act that defines the scope of the agency's power. Other proponents of administrative reform proposals have sought procedural changes, but nost of these changes would only supplement rather than supplant the original APA. ${ }^{13}$

9. The outstanding single development in administrative law and in the administrative agencies of the last half-century, unquestionably, is the genesis and enactment of the Administrative Procedure Act. Oddly, the second most important developinent has been the lack of amendinent to the Administrative Procedure Act and of radical change in the structure and function of the administrative agencies, in spite of strong prcssures for change throughout the latter half of the period.

Williams, Fifty Years of the Law of the Federal Administrative Agencies-and Beyond, 29 FED. B.J. 267, 268 (1970).

10. J. Freedman, Crisis and Legitimacy 3-12 (1978).

11. See, e.g., Senate Comm. on Governmental Affairs, 95th Cong., 2d Sess., Study on Federal Regulation 5 (Comin. Print 1977); Subcomm. on Oversight and Investioations, House Comm. on Interstate and Foreign Commerce, 94til Cong., 2D Sess., Federal Regulation and Regulatory Reform 487-501, 547-49 (Comin. Print 1976)(consolidation of multiple agency functions under single agency); THE PRESIDENT's ADVISORy Council on Executive Organization, A New Regulatory Framework: Report on SELECTED INDEPENDENT REGULATORY AGENCIES 13-26 (1971)(single administrators in areas of transportation, power, securities, and consumer protection regulation); Hector, Problems of the CAB and the Independent Regulatory Commissions, 69 YALE L.J. 931, 960 (1960)(recommending abolition of independent comunissions).

12. See T. Lowi, THE END of Liberalism 287-314 (2nd ed. 1977)(revival of delegation doctrine and return to juridical democracy); THE CRISIS OF THE REgulAtORY CoMmission (P. MacAvoy ed. 1970)(deregulation); Promoting Competition in Regulated Markets (A. Phillips ed. 1975)(deregulation); see also H. Friendly, THE Federal Administrative Agencies: THE NEED FOR BETTER DEFINITION OF STANDARDS 1-26 (1962)(agencies should create clear standards by rule if Congress lias not done so).

13. For example, the first inajor cliange in the APA was the addition of the Freedorn of Information Act (FOIA) in 1966. See Pub. L. No. 89-554, 80 Stat. 378, 383 (1966)(codified as amended at 5 U.S.C. $\S 552$ (1982)). The FOIA clarified the obligation of agencies to provide information and documents to the general public, a subject on which the APA had been silent. Since then the Government in the Sunshine Act, 5 U.S.C. \& 552b(1982), and the Regulatory Flexibility Act, 5 U.S.C. $\$ \S 601-612$ (1982), lave also added discrete requirements for public access to 
Since the APA becaine law, constant scrutiny of and dissatisfaction with administrative agencies have produced these demands for reform. Pressure for reform has intensified recently because of the growth in the scope and social impact of federal agency rulemaking. Although the magnitude of federal rulemaking has increased steadily since World War II, a significant surge began in the mid-1960's when the federal government began responding to new social and econoinic problems in such fields as consumer protection, environmental quality, affirmative action, occupational health and safety, and educational quality. ${ }^{14}$ This surge produced both new laws and new agencies; twenty of the fifty-six federal regulatory agencies were created between 1970 and $1979.1^{15}$ The number of full-time agency employees increased from 28,000 to 87,000 in the same period. ${ }^{16}$ The size of the Federal Register, the government periodical in which proposed federal regulations are publislied and final regulations are announced, grew from 20,000 pages in 1970 to more than 80,000 by 1980.17 The Code of Federal Regulations, in turn, expanded from 54,000 pages in 1970 to 93,000 in 1979.18

The treinendous recent growth in the number of Washington lobbyists, Washington-based law firms, and law firms with Washington offices $^{19}$ attests to the current significance of the federal government in our society and economy. The practice of these lobbyists to work the halls of bureaus as frequently as the halls of Congress, and of Washington lawyers to invest inany inore hours in practice before agencies than before courts, signifies the central importance of the agencies in that government.

The growth in agency work and influence has produced protests froin adversely affected groups. Prompted by this outcry, Congress has

agency deliberations, and for agency consideration of the total effects of its actions, in light of available alternatives.

14. See P. MacAvoy, The Regulated Industries and the Economy 9 (1975)("This expansion was gradual at first but, since the late 1960's, the growth of agency control has been explosive. The inotive, then, was to use the regulatory process to increase liealth, safety, and the quality of the environment.").

15. S. REP. No. 284, 97th Cong., 1st Sess. 9-13 (1981) (citing to sources).

16. Id.

17. Id. at 11 .

18. Id.

19. Between 1975 and 1979 , the number of lawyers engaged in regulatory practice in the District of Columbia more than doubled. It's a Bull Market for Lawyers Here, Legal Times of Wash., June 11, 1979, at 25, col. 1. Until the Reagan Administration took office, however, no glut was discernible because the government continued to generate new sources of regulatory busmess faster than lawyers could flock to them. D.C. "Business as Usual" to Remain So, Legal Times of Wash., April 21, 1980, at 1, col. 1. 
recently been questioning whether the administrative state is fundamentally flawed-whether it suffers from "regulatory failure." Although species of regulatory failure are probably as numerous as species of nnarket failure, they can be divided into two general categories, substantive and procedural. The term substantive failure describes an error in designing statutory means to accomplish a stipulated end, causimg failure despite flawless implementation. The term procedural failure denotes undesirable effects that derive from the impleinentation process itself.

For example, if Congress enacted a law intended to reduce efficiency losses associated with market failure, such as monopoly power or prices that do not reflect the true social costs of production, a regulation written to implement that law would fail substantively if, even when implemented exactly as intended, it did not correct the efficiency losses. ${ }^{20}$ Procedural regulatory failure could occur in two ways in this example. First, the implementation process itself could interfere with the desired market failure correction, in this case by reducing the net benefits that would flow from elimination of the efficiency losses. Second, the implementation process could generate undesirable side effects, such as significant adverse distributional consequences, delays,

20. The Averch-Johnson effect is perhaps the best-known example of substantive regulatory failure. See Averch \& Johnson, Behavior of the Firm Under Regulatory Constraint, 52 AM. EcoN. REv. 1052, 1953-69 (1962). Averch and Johnson constructed a model of rate-of-return regulation that shows that utilities subject to this form of regulation possess a strong incentive to overutilize capital when they are granted rates of return exceeding their costs of capital. The design of this regulatory system itself, while aimed at reducing the allocative inefficiency due to excessive monopoly pricing, produces inefficiency through overcapitalization. $I d$.

Note, also, that particular regulations may only partially solve a market failure problem. Some regulatory solutions will be more successful at reducing the efficiency loss from monopoly power than will others. Thus, substantive regulatory failure can occur when a particular regulation corrects market failure less effectively than other regulations.

Inefficiency is only one example of market failure; statutes or regulations can be designed to correct for other types of failure as well. Determining whether those regulations fail substantively requires comparing the objectives and means of the regulations with their ability to correct those failures. For instance, a legislature might pass a statute imposing a moratoriun on collecting rent from impecunious widows in order to correct a perceived distributional failure. Its intended result, therefore, would be a transfer of wealth to widows. Nevertheless, the moratorium inight fail because of secondary reactions in the private sector from, for example, landlords who, having a choice, might elect to avoid renting to widows or to charge rent premiums for the additional risks of nonpayinent created by the moratoriun legislation. See Leff, Economic Analysis of Law: Some Realism about Nominalism, 60 VA. L. Rev. 451, 460-61 (1974); Michelman, Reflections on Profes. sional Education, Legal Scholarship, and the Law-and-Economics Movement, 33 J. LEGAL. EDUC. 197, 206-08, 206 n.31 (1983)(discussing the confounding influences of changes in empirical contingencies on the law's ultimate impact). Furthermore, whether those ultimate effects constitute a substantive failure of the legislation turns on a more precise definition of the legislative end. Second order effects, for example, might bear only ininimally on the success of the moratorium if the intention is just to give short term relief to a specific class of beneficiaries. 
reduced agency productivity, increased participation costs, or reduced legitimacy of the agency's rules.21

Implementing statutes through regulations will always generate some costs and, so long as imdividuals have private interests that diverge from the goals of the regulation, the effect of the regulation will always fall short of the ideal. Whether a particular regulatory procedure fails will therefore ultimately rest on a judginent coinparing the shortcomings and side effects of the procedure with those of feasible alternatives. In addition, the final effect of a regulation depends on both its design and its implementation, so that any assessinent of a regulatory scheme will require an integrated assessment of substance and procedure. ${ }^{22}$

The regulatory reform movement of the last decade claims to have identified imstances of both substantive and procedural failure in the regulatory state. ${ }^{23}$ Substantive failures have received the most attention, and two political responses have been advanced to eliminate them. First, it has been suggested that naturally competitive industries be deregulated. Implemented examples of this response mclude the Airline Deregulation Act of 1978, ${ }^{24}$ the 1978 Natural Gas Policy Act ${ }^{25}$ deregulatimg gas prices, the Motor Carrier Act of $1980^{26}$ deregulating trucking, the 1980 Staggers Rail Act ${ }^{27}$ relaxing railroad regulation, the 1981 admimistrative deregulation of oil prices, ${ }^{28}$ and the 1982 settlement between AT\&T and the Justice Department deregulatimg large portions of the telecommunications industry. ${ }^{29}$ Second, it has been suggested that flawed regulatory methods be replaced. This suggestion has generally required discarding traditional command-and-control

21. See infra part VI (discussion of these criteria for evaluating the social desirability of a regulation).

22. For other methods of organizing types of regulatory failure, see generally S. BREYER, Regulation AND ITS REFORM (1982); Wolf, A Framework for Implementation Analysis: $A$ Theory of Non-Market Failure, 22 J. LAW \& EcON. 114 (1979).

23. See, e.g., E. Bardach \& R. Kagan, Social Regulation: Strategies for Reform 319, 361 -75 (1982); R. Litan \& R. NoRdHAus, Reforming Federal Regulation 59-99 (1984).

24. Airline Deregulation Act of 1978, Pub. L. No. 95-504, 92 Stat. 1705 (codified at scattered sections at 49 U.S.C. (Supp. V. 1981)).

25. Natural Gas Policy Act of 1978, Pub. L. No. 95-621, 92 Stat. 3350 (codified at 15 U.S.C. $\S \S 3301-3432,42$ U.S.C. $\$ 7255$ (Supp. V 1981)).

26. Motor Carrier Act of 1980, Pub. L. No. 96-296, 94 Stat. 793 (codified at 49 U.S.C. $\S \S 10,101-11,902 \mathrm{a}$ (Supp. V 1981)).

27. Staggers Rail Act of 1980, Pub. L. No. $96-448,94$ Stat. 1895 (codified at 11 U.S.C. $\S \S 1170,1172$ (1982), 45 U.S.C. $\S \S 231$-10I8 (Supp. V 1981), 49 U.S.C. $\$ \S 1654 a, 10,101-11,913 a$ (Supp. V 1981)).

28. Exec. Order No. 12,287, 3 C.F.R. 124 (1981).

29. See United States v. AT\&T, 552 F. Supp. 131 (D.D.C. 1982). 
regulations in favor of market incentive devices, including taxes, fees, and property rights that can be traded. ${ }^{30}$

Despite the reform movement's preoccupation with substantive failure, it has not neglected the problems of procedural failure. For some time, Congress has remedied various procedural failures by incorporating process reform into specific statutes. ${ }^{31}$ These case-by-case adjustments of the administrative process may actually have contributed to the APA's stability by preventing reform pressures from being focused on the generic procedural statute. In recent years, however, Congressmen have regularly proposed bills to amend the APA, ${ }^{32}$ indicating that such msulation may be wearmg thin. These recent reform bills reflect recurring themes such as tightening judicial review, expandimg procedural constramts on informal rulemaking, requiring impact analysis for major regulations, legislating the role of the Office of Management and Budget (OMB) im the regulatory process, and enacting an across-the-board legislative veto provision.

Having distinguished some possible shortcomings in both the substance and process of regulation, the remaimder of this article focuses on procedural reform. An implicit assumption im this exercise is one we alluded to earlier-administrative procedures and the system in which they reside are vitally important to the sound functioning of modern government. To define more clearly why reform of the administrative process raises important questions, and before we can accurately describe our method of evaluating suggested reforms, we must first clarify and defend this assumption. We must consider why the process itself warrants such attention.

30. For example, the Environmental Protection Agency's Emissions Trading Policy is designed to achieve more air pollution control at lower cost than the 1970 Clean Air Act approach. See Emissions Trading Policy Statement: General Principles for Creation, Banking and Use of Emission Reduction Credits, 47 Fed. Reg. 15,076 (1982). See generally F. ANDERson, A. KNEese, P. Reed, R. Stevenson \& S. TAyLor, Environmental Improvement THrough EcoNomic Incentives (1977); R. Nordhaus \& R. Litan, Reforming Federal Regulation (1984); C. Schultz, The Public Use of the Private Interest (1977); InCentives for EnviRONMENTAL PROTECTION (T. Schelling ed. 1983). For a review of some of the Environmental Protection Agency's ideas under the Carter Administration, see Drayton, Getting Smarter About Regulation, HARv. BuS. REv. July-Aug. 1981, at 38.

31. For instance, it has imposed additional procedures on agency rulemaking above the APA minimum for inforinal ruleunaking. See, e.g., Federal Trade Comunission Improvements Act, 15 U.S.C. \& 57a (1982)(FTC rulemaking); 15 U.S.C. \& 78f(e)(4)(A)-(E) (1982)(SEC rulemaking); The Toxic Substances Control Act of 1976, 15 U.S.C. $\$ 2605$ (1982)(EPA rulemaking for toxic chemicals). See generally Verkuil, The Emerging Concept of Administrative Procedure, 78 ColUM. L. REv. 258, 317-20 (1978)(collecting examples).

32. See infra notes $58-60$ and accoinpanying text. 


\section{ADMINISTRATIVE DiscRetion}

If agencies closely followed the detailed desires of Congress when carrying out their statutory responsibilities, the problein of improving agency-made regulations would collapse into the problein of improving Congress. Agencies do exercise discretion, however, in the sense that they are empowered to choose froin two or nore permissible ways to implement their statutory authority. ${ }^{33}$ The sheer power agencies exercise compels us to be concerned about the procedures through which they operate, because the procedures channel the exercise of that power.

For some time, a central question for both administrative and pohtical theory about the democratic state has been how to reconcile the existence and performance of administrative agencies with the expression of popular will that legitimates legislative governmental authority. ${ }^{34}$ Only recently, however, have critics focused explicitly on the existence of agency discretion as the crucial element in that question. In the past, the problem of discretion was muted by changing combinations of theories and controls-theories justifying discretion, and controls channelling it into acceptable avenues. Understanding how these older combinations failed helps to explain discretion's current status.

33. We are using discretion in the same sense as Hart and Sacks: "[D]iscretion means the power to choose between two or more courses of action each of which is thought of as permissible." H. Hart \& A. Sacks, The Legal Process: Basic Problems in the Making and AppliCATION OF LAW 162 (10th ed. 1958); see also L. JAFFe, Judicial Control OF ADMINISTRATIVE ACTION 586 (1965) ("Discretion . . . is the power of the administrator to make a choice froin among two or more legally valid solutions."). In Ronald Dworkin's terms, the discretion we mean corresponds roughly to "strong discretion." See R. Dworkin, Taking Rights Seriously 31-39 (1977). The claim that agencies exercise discretion does not depend, however, on choosing sides im the debate between Dworkin and Sartorius on the one hand, and H.L.A. Hart and Hart and Sacks on the other, over whether legal questions always have a single right answer. Compare R. DworKIN, supra, at 81 ("I shall argue that even when no settled rule disposes of the case, one party may nevertheless have a right to win. It remains the judge's duty . . . to discover what the rights of the parties are, not to invent new rights retrospectively.") with H.L.A. HART, THE CONCEPT OF LAW 124 (1961)("The discretion thus left to [a judge] inay be very wide; so that if he applies the rule, the conclusion, even though it may not be arbitrary or irrational, is in effect a choice."). Discretion in our terms means (l) the apparent absence of a single, indisputably correct description of the rule an agency should adopt, after inspection of the statute, the available legislative history, and other relevant materials, which implies (2) a substantial belief that a reviewing court would uphold any rule that the agency selected from among a set of plausible choices. This discretion cannot be eliminated completely. See Monaghan, Marbury and the Administrative State, 83 Colum. L. Rev. 1, 25 \& n. 148 (1983)(proposals to limit agency discretion concede that substantial Hart and Sacks discretion would reinain); see also infra note 56.

34. See Stewart, The Reformation of American Administrative Law, 88 HARv. L. REv. 1667, 1675 (1975)("Insofar as statutes do not effectively dictate agency actions, individual autonomy is vulnerable to the inposition of sanctions at the unruled will of executive officials . . . who are not formally accountable to the electorate."). 
Early Supreme Court doctrine limited the discretion that Congrcss could delegate to agencies. ${ }^{35}$ Agencies could only exercise the authority given them by legislation, so they had no independent lawmaking capacity. To transmit authority to them, Congress had to give agencies an "intelligible principle" to guide administration. ${ }^{36}$ So confined, the agencies' work was, in theory, limited to implementing the specific details-or filling in the gaps-of a well-defined legislative scheme. The constitutional principle prohibiting the delegation of legislative power was the foundation of both this theory and the concomitant limitations on statutory grants of power to the agencies.

The increased delegation of authority to New Deal agencies and the growth of the modern welfare state stretched this approach to discretion to the breaking point. The urgent deinands of the economy in the 1930's, the willingness of the people and the Congress to place substantial power in the hands of the executive, and the consensus that some central planning and policy measures were essential to economic recovery and stability combimed to produce more powerful regulatory agencies. In two Depression-era cases, Panama Refining Co. v. Ryan ${ }^{37}$ and A.L.A. Schechter Poultry Corp. v. United States, ${ }^{38}$ the Supreine Court upheld the older interpretation of the delegation doctrine by invalidatimg provisions of the National Industrial Recovery Act as unconstitutional delegations of legislative authority to adininistrative agencies. The decisions provoked one of history's most dramatic confrontations between the judiciary and the executive. The "switch in time that saved nine"39 thwarted President Roosevelt's court packing scheme and led to a Supreme Court majority that upheld the broad delegation of power to agencies.

35. See, e.g., United States v. Grimaud, 220 U.S. 506, 517 (1911)(Court sustained delegation to Secretary of Agriculture of power to niake rules protecting national forests froin fire because Secretary had simply been given " "the power to fill up the details" " of a congressional decision); Buttfield v. Stranahan, 192 U.S. 470, 494-98 (1904) (Court upheld tea inspection act as proper delegation of authority); Field v. Clark, 143 U.S. 649, 692-93 (1892)(delegation of authority to president to invoke a retaliatory tariff schedule was permissible because act "does not, in any real sense, invest the President with the power of legislation. . . . [The President was] the mere agent of the law-nraking department to ascertain and declare the event upon which [Congrcss's] expressed will was to take effect").

36. J.W. Hainpton \& Co. v. United States, 276 U.S. 394, 409 (1928).

37. 293 U.S. 388,431 (1935).

38. 295 U.S. 495,539 (1935).

39. The phrase refers to Supreme Court decisions in 1937 upholding parts of President Roosevelt's New Deal legislation after the Schechter and Panama Refining decisions had created speculation that the entire new deal strategy was in jeopardy at the hands of the Court. See generally Leuchtenburg, Franklin D. Roosevelt's Supreme Court "Packing" Plan, in Essays oN THE NEW DEAL 49 (H. Hollingsworth \& W. Holmes ed. 1969); Leuchtenburg, The Origins of Franklin D. Roosevelt's “Court-Packing" Plan, 1966 SuP. CT. REv. 347. 
New agencies began operating under instructions no more specific than to advance the "public interest" 40 and another theory emerged to explain agency discretion. Proponents of this theory also described agency discretion as limited-limited not by lack of agency independence as in the old model, but by their mandate to exercise a skilled judgment in the service of an objective well-defined by the legislature, an exercise of judginent that was believed to lead to a definite "correct" result over time. ${ }^{41}$

This expert manager theory dissolved, too, as it became clear that the public interest does not always dictate a single result in many important areas of regulation. The public has many interests, and interest groups, each differently affected by regulatory alternatives and each with different claims to consider. ${ }^{42}$ Congress theoretically could mandate a regulatory goal with sufficient specificity to make it consistent with the model of agencies as experts, but until now it has been either unable or unwilling to do so. ${ }^{43}$

Both the expert manager model and the earlier gap-filling model established substantive criteria that theoretically restricted the agencies' freedom to formulate policy and promulgate rules. The failure of these models left the administrative state with agencies with substantial discretion, but without confidence that the discretion would be sufficiently controlled. With the decline of these theories, efforts to solve the dis-

40. For example, The Federal Communications Commission is instructed to determine whether "the public interest, convenience and necessity will be served" by granting an application for a radio station hicense. 47 U.S.C. \$ 309(a) (1976).

41. See Diver, Policymaking Paradigms in Administrative Law, 95 HARv. L. REv. 393, 409-13 (1981); Stewart, supra note 34, at 1678-81. The expectation that expertise could control discretion and thus avoid arbitrarimess is frequently reflected in judicial opinions. See, e.g., ICC v. Chicago, R.I. \& P. Ry., 218 U.S. 88, 102 (1910)(The ICC's authority is "expected to be exercised in the coldest neutrality. . . . [T] he training that is required, the comprehensive knowledge that is possessed, guards or tends to guard against the accidental abuse of its powers . . . .").

42. Stewart, supra note 34 , at 1682-83; see Diver, supra note 41 , at 422-23.

43. In recent years several cominentators, remarking on the congressional tendency to enact vague laws, have urged revival of the nondelegation doctrine. See, e.g., Industrial Union Dept., AFL-CIO v. American Petroleum Inst., 448 U.S. 607, 687-88 (1980)(Rehnquist, J., dissenting)(the Benzene case); J. Ely, DEMOCRACY AND DistruST 131-34 (1980); Gellhorn, Robinson \& Aranson, A Theory of Legislative Delegation, 68 CORNELL L. REV. 1 (1983); Gewirtz, The Courts, Congress, and Executive Policy-Making: Notes on Three Doctrines, LAW \& ConTEMP. Probs., Summer 1976, at 46, 56-61; McGowan, Congress, Courts and Control of Delegated Power, 77 Colum. L. REv. 1119, $1127-30$ (1977); Wright, Beyond Discretionary Justice, 81 YALE L.J. 575, 582-87 (1972); see also T. Lowi, The END of LiBeralism 287-314 (2nd ed. 1977). Whatever the merits of greater specificity in statutory language, we doubt that discretion can be removed from the administrative state through revival of the delegation doctrine. See infra notes 54-56 and accompanying text; see also Stewart, supra note 34, at 1693-97 (doubting wisdoin of a judicial revitalization of the delegation doctrine). 
cretion puzzle turned both to the internal procedures of the agency and to the more frequent review of agency performance by Congress.

The APA was Congress's first attempt to establish procedural regularity in agency practice. It recognized two types of rulemaking procedures: formal ${ }^{44}$ and informal ${ }^{45}$ rulemakmg. In the past twenty years, informal rulemaking, with its minimal notice and coinment requirements, has become the technique used by many agencies. Because the number and scope of such agencies increased simultaneously, and because informal rulemaking is too limited to bear the full weight of agency discretion, federal courts responded by examining agency action more closely and by channehing discretion through additional procedural safeguards. ${ }^{46}$ These judicial innovations reflected efforts to conform agency practices to notions that the judges thought were "inherent in the very concept of a fair hearmg." 47 They also illustrated a

44. 5 U.S.C. $\S \S 556(e), 557$ (1982). Where commanded by law to use formal rulemaking, agencies inust hold hearings resembling customary courtroom trials, with a hearing examiner receiving evidence from parties who have the right to present testimony, to object, and to crossexamine witnesses. The trial produces a record, which must be the sole source of factual information on which the rule is based. See generally Hamilton, Procedures for the Adoption of Rules of General Applicability: The Need for Procedural Innovations of Administrative Rulemaking, 60 Calif. L. Rev. 1276 (1972).

45. Inforinal rulemaking, governed by section 553, 5 U.S.C. $\S 553$ (b)-(c) (1982), has only minimal requirements of notice and comment. The agency is required to provide advance notice of its intention to promulgate a regulation, and to seek comment from any interested parties. After a period of time in which such comments, usually in writing, could be considered by the agency, the agency issues the regulation, taking such aceount of the comments as it considers warranted. For a concise summary of the imformal rulemaking process, see DeLong, Informal Rulemaking and the Integration of Law and Policy, 65 VA. L. REV. 257 (1979).

46. See, e.g., Citizens to Preserve Overton Park, Inc. v. Volpe, 401 U.S. 402, $415-16$ (1971); Home Box Office, Inc. v. FCC, 567 F.2d 9, 53-54 (D.C. Cir.), cert. denied, 434 U.S. 829 (1977). Courts channeled agency discretion by requiring notices of rules to mclude notice of the data and methodology on which the agency was relying, Portland Cement Ass'n v. Ruckelshaus, 486 F.2d 375, $391-93$ (D.C. Cir. 1973), cert. denied, 417 U.S. 921 (1974); United States v. Nova Scotia Food Prods. Corp., 568 F.2d 240, 252 (2d Cir. 1977), by requiring agencies to grant rights to present oral testimony and cross-examination, e.g., Bunker Hill Co. v. EPA, 572 F.2d 1286, 1305 \& n.41. (8th Cir. 1978); Appalachian Power Co. v. EPA, 477 F.2d 495, 503 (4th Cir. 1973)(dictum); cf. Walter Holm \& Co. v. Hardin, 449 F.2d 1009, 1015 (D.C. Cir. 1971) ("The kind of procedure required must take into account the kind of questions involved"), and by insisting that agencies issue an additional general notice if their proposal undergoes significant changes after the proceedings begin, Portland Cement Ass'n, 486 F.2d at 394; Automotive Parts Accessories Ass'n v. Boyd, 407 F.2d 330, 338 (D.C. Cir. 1968). Courts also required that agencies fully explain their final decisions, particularly by responding to material criticism from interested parties. Rodway v. United States Dept. of Agriculture, 514 F.2d 809, $816-17$ (D.C. Cir. 1975); Office of Coinmunications of the United Church of Christ v. FCC, 560 F.2d 529, 532-33 (2d Cir. 1977); see Nova Scotia Food Prods., 568 F.2d at 252 . These judicial innovations have been slowed by the Supreme Court's ruling that courts can impose procedures beyond those speeified in the APA only in "extraordinary circumstances." Vermont Yankee Nuclear Power Corp. v. Natural Resources Defense Council, 435 U.S. 519, 543-44 (1978).

47. American Airlimes v. Civil Aeronautics Board, 359 F.2d 624, 632 (D.C. Cir. 1966). 
shift from a view of agencies as operating with clear mandates and tightly restrained power to a view of agencies as acting without clearly preferable policy options but with substantial discretion. Thus, the expert manager model was smothered under a more realistic, even cynical, appraisal of agency operations. ${ }^{48}$

While the courts examined agency procedures, Congress also reacted. During the 1960's and 1970's Congress began to follow a new agenda for controversial social issues. It involved restraining the client groups of established agencies, or regulating segments of industry and commerce in the name of causes such as consumer welfare and environmental protection. Aware of the criticisin that the established agencies had been captured by their clientele, Congress created new agencies to implement its new agenda. Not only were these agencies new, many of thein were given statutory instructions quite different from the older public interest statutes. The new statutory mandates often imposed a strict deadline, ${ }^{49}$ dictated a specific approach to agency

48. Studies of agency regulatory actions have shown a pattern of solicitude for the interests of the industries ostensibly the objects of the regulation. See G. Schubert, THE Public INTEREsT 119 (1960); Green \& Nader, Economic Regulation vs. Competition: Uncle Sam the Monopoly Man, 82 Yale L.J. 871, 876 (1973); see also J, Landis, The Administrative Process 36-37 (1938). As the "public interest" disintegrated into a collection of special interests, critics saw agency client groups obtaining special advantages, rather than a neutral agency protecting the public interest. Students of organizational behavior and economics provided confirming evidence and explanations. Agency personnel depended on industry for information and political support. Career bureaucrats seemed to prefer a work pattern of amiable relations and consensus to one of strife and tension, and sueh a pattern required cooperation with and from the industry. The task of regulation included maintaining a healthy and stable clientele, and a strong regulated group also promoted congressional support and budgetary growth. Diverse evidence and theories merged to create a disturbing picture of bureaus endowed with substantial discretionary powers unchecked by some neutral expertise or discipline, favoring the interests of client industries over broader interests or less concentrated groups; e.g., M. BERNSTEIN, REGULATING BUSINESS BY INDEPENDent Commission 87 (1955); R. Fellmeth, The Interstate Commerce Omission 1-39 (1970); J. Landis, Report on Regulatory Agencies to the President-Elect 71 (1960); see also Stigler, The Theory of Economic Regulation, 2 BeLl J. ECON. \& MGMT. SCI. 3 (1971).

The studies illustrated a process for rulemaking that was, in important respects, political. Rules were created through negotiation and compromise, and those rules reflected a sense of what was possible and what was necessary to ensure the pohtical stability of the agency. Rulemaking reseinbled lawinaking by Congress and congressional committee. Yet, the accepted procedures produced a highly skewed political process-one in which only a severely truncated portion of the relevant issues and groups were represented. This allowed the exercise of agency discretion in ways far removed from the popular will. From this perspective, the procedural additions to informal rulemaking expanded the interests represented and participating in regulation writing. Tliey provided "a surrogate political process to ensure the fair representation of a wide range of affected interests." Stewart, supra note 34, at 1670.

49. For example, Congress gave the Environmental Protection Agency 120 days from the effective date of the Clean Air Act Amendments of 1970 to issue air quality standards for sulphur dioxide, particulates, nitrogen oxides, carbon monoxide, and hydrocarbons. 42 U.S.C. 
action, ${ }^{50}$ or defined a specific result that the regulation was to achieve. ${ }^{51}$ These provisions are examples of "agency-forcing" statutes, ${ }^{52}$ which attempt to channel agency discretion into more precisely controlled avenues than did the public interest statutes of the established agencies. They reflect Congress's suspicion of unrestrained discretion in the hands of agencies. Experience under these recent efforts to cabin discretion has demonstrated, however, that while they may affect the ways discretion is employed and the directions in which it can move, they do not entirely eliminate opportunities for the agency to exercise it.

Despite Congress's agency-forcing imtentions, the vast majority of the new statutes can still be implemented in a variety of ways, and to that extent they do not remove discretion from the administrative system. For instance, under the Clean Air Act, ${ }^{53}$ the Environmental Protection Agency (EPA) must decide what constitutes the "best system of emission reduction" that "has been adequately demonstrated" for air pollution fron imdustrial sources. This decision may seem at flrst glance to be an objectively determinable, technical one, but it is not. "Best . . . adequately demonstrated" may be interpreted as the best technology currently im use, the best technology for which rehable commercial or pilot plant test results are available, the best technology that could plausibly be transferred from another industry, or the best technology that experimental results and theoretical work appear to support. Any one of these approaches would satisfy the statutory mandate, ${ }^{54}$ yet the definition selected will have dramatic effects on the

§ 7409(a)(1) (Supp. V 1981). The standards also had to be based on scientific, health-based considerations that further limited agency choice. Id. at $\$ 7409(\mathrm{~b})(1)$.

50. For instance, Congress has required that standards be based on technology assessment, e.g., 42 U.S.C. $\$ 741$ I (Supp. V 198I)(Clean Air Act new source performance standards), or solely on health considerations. See, e.g., supra note 49.

51. For instance, the Clean Air Act Amendments of 1970 instructed the EPA to set automobile emissions standards so as to reduce such emissions by $90 \%$. 42 U.S.C. $\$ \S 1857 \mathrm{~b}-18571$ (1976).

52. For further discussion of "agency-forcing" statutes, see B. ACKERMAN \& W. HASSLER, CleAn COAL/DirTy Air 124-28 (1981).

53. 42 U.S.C. \& $7411(a)(7)(c)$ (Supp. V 1981).

54. The EPA has variously interpreted analogous provisions in both the Clean Air Act and the Clean Water Act to permit each of these definitions. For intcrpretations of the Clean Air Act, see Portland Cement Co. v. Ruckelshaus, 486 F.2d 375, 395-402 (D.C. Cir. 1973), cert. denied, 417 U.S. 921 (1974)(commercial plant tests satisfied definition); Essex Chemical Corp. v. Ruckelshaus, 486 F.2d 427, $433-37$ (D.C. Cir. 1973)(same); Sierra Club v. Costle, 657 F.2d 298, 360-67 (D.C. Cir. 1981)(one conmercial plant test, one pilot plant test, plus projected design and operation improvements satisfied definition). For interpretations of the Clean Watcr Act, sec American Paper Inst. v. Train, 543 F.2d 328, $351-52$ (D.C. Cir.), cert. dismissed, 429 U.S. 967 (1976)(technology to be transferred from other industry categories satisfied definition); California \& Hawaiian Sugar Co. v. EPA, 553 F.2d 280, 285-89 (2d Cir. 1977)(same); Hooker Chemicals \& Plastics Corp. v. Train, 537 F.2d 620, 632 (2d Cir. 1976)(results of exemplary cominercial plants formed adequate regulatory basis). The EPA has frequently been reversed in its application of these definitions to 
stringency of emission standards, the speed with which rules can be written for different industries, and the expense imposed on industry. Even mandating the use of cost-benefit analysis will not eliminate discretion, given that many assuinptions inust be made, hard-to-quantify factors must be quantified, shadow prices must be approximated for factors for which no market price is available, and assessments must be made of regulatory outcomes..$^{55}$ Although agency-forcing inay have other merits, it is unlikely to eliminate discretionary power. ${ }^{56}$

specific industries, but judicial interpretation affirms the EPA's discretion to choose among the alternative defiuitions. See, e.g., Portland Cement v. Ruckelshaus, 486 F.2d at 391 (discussing "adequately demonstrated"); Tanners' Council of America v. Train, 540 F.2d 1188, 1192 (4th Cir. 1976) (adequacy of technology is "ahnost entirely judginental"); see also infra note 56.

55. See, e.g., Subcomm. ON Oversight AND Investigations of House COMM. ON INTERState and Foreign Commerce, 96Th Cong., 2D Sess. Cost-Benefit Analysis: Wonder TOOL OR Mirage? 1-31 (Comm. Print. 1980).

56. The EPA's recent revisions of the new source performance standards for coal-fired power plants provide an excellent example of the discretion that remains in modern rulemaking processes, even under agency-forcing regimes. Sulphur oxides are among the most critical pollutants produced from fossil fuel combustion, and power plants among the major producers of this pollutant. Control technologies for sulphur emissions from power plants are extremely expensive. As the EPA reviewed the proposed standards, it considered controlling both the percentage of sulphur that had to be removed and a maximum amount that could be emitted for every million British thermal units (MBtu's) of coal energy consumed. The EPA's final rule established a percentage removal requirement varying with the sulphur content of coal as well as a ceiling of 1.2 pounds of sulphur dioxide per MBtu. Utility companies challenged that aspect of the percentage removal rule requiring $90 \%$ renoval for high sulphur content coal; the Environmental Defense Fund (EDF) contested the $1.2 \mathrm{lbs}$./MBtu ceiling.

Both the rulemaking aud the subsequent judicial review were vigorously litigated by utility consortia, individual utilities, the National Coal Association, the EDF, the EPA, and other interested parties. Judicial review could have been expected to be, and was, thorough and probing. Ultimately, the Court of Appeals for the District of Columbia Circuit upheld the EPA rule, including the two sulphur content control elements just described. Sierra Club v. Costle, 657 F.2d 298, 360-64 (D.C. Cir. 1981). More inportant than the actual result, however, is our judgment about the outcome had the EPA issued a different rule on the basis of precisely the sane record and operating under the identical statute. The court's discussion of the EPA's $90 \%$ removal standard abounds with references to EPA inferences and extrapolations from existing data; the court reinarked several times that parts of the EPA's reasoning cannot be supported by data of performance from existing or pilot facilities. 657 F.2d at 360-73. To justify the $90 \%$ standard, the EPA had to rely upon its projections of "some design and operational improvements" in new control technology. Id. at 363. While concluding that the "EPA has plotted a reasonable course through the evidentiary thicket and stated a logical rationale for the route it chose," id. at 360 , the court almost certainly would have sustained a less stringent standard had the EPA "chosen" to rely less heavily on such projections and extrapolations, and thus to produce a less stringent standard. $C$ f. Ethyl Corp. v. EPA, 541 F.2d 1, 37 (D.C. Cir. 1976)("Thus we might well have sustamed a determination by the Adininistrator not to regulate. . . . That does not mean, however, that we cannot sustain his decision to so regulate.").

This reading of Sierra Club shows that the EPA possessed discretion to choose among plausible alternative standards. It is consistent with the Supreme Court's current view of the authority agencies have frequently been given by Congress. Where the agency's judginent constitutes " 'a reasonable accommodation of conflicting policies that were committed to the agency's care by the statute," " the court reviews "only to deterunme whether [it] has exceeded [its] statutory authority 
Rather than extracting all discretion from agency directives, Congress might resort to increased post hoc scrutiny of the agencies' work. In fact, oversight hearings, budget-related hearings, and government operations subcommittees' hearings have markedly increased in recent years. Now that control of agency discretion through the legislative veto has been foreclosed, Congress may rely upon these types of oversight even more frequently. Such oversight is unlikely to be continuous, however, and even when present it can be incorporated into the model we will describe by treating it as another procedural ingredient in the formulation of agency rules, like judicial review.

Our maturing appreciation of the administration of laws has produced a sense that substantial discretion is inevitable in any modern governmental structure that relies upon agencies to implement complicated prograins of regulation. We have put aside earlier pretensions that discretion is merely residual or mechanical or that it can be controlled by neutral application of expert techniques of analysis and admimistration. This observation, however, leaves unresolved the puzzle of reconciling the rule of admmistrative agencies with theories of representative democracy.

\section{Procedural Reform and Its Social Consequences}

\section{A. The Internal View of Procedure.}

1. Procedure Important for Its Own Sake. Since the mid-1960's, Congress and agency critics have brought pressure to bear on the procedural aspects of agency operations. Both the House and Senate have conducted substantial hearings. ${ }^{57}$ In 1982 , the Senate formalized its

or acted arbitrarily." Fidelity Federal Sav. \& Loan Ass'n v. De la Cuesta, 458 U.S. 141, 154 (1983)(citing United States v. Shimer, 367 U.S. 374, 381-82 (1961)). The court's task, in short, is not to determine whether it would have reached the same result as the agency, but only to decide whether the regulation chosen was a "reasonable" one. That distimction presupposes that more than one "reasonable" rule is generally available to the agency.

57. E.g., Committee on Governmental AfFairs, Study on Federal Regulation S. Doc. Nos. 25-26, 71-72, 95th Cong., 1st Sess. (1977), S. Doc. No. 91, 95th Cong., 2d Sess. (1977), S. Doc. Nos. 13-14, 96th Cong., 1st Sess. (1978)(six vols. plus an appendix to vol. six, published between Jan. 1977 and Dec. 1978); Regulatory Reform: Hearings Before the Subcomm. on Administrative Practice and Procedure of the Senate Comm. on the Judiciary, 96th Cong., 1st Sess. (1979) (summarized in S. REP. No. 1018, 96th Cong., 2d Sess., pt. 2 at 14-16 (1980)); Administrative Proce. dure Act Amendments of 1978: Hearings on S. 1463, S. 1720, S. 1721, S. 2011, S. 2490, S. 2862 Before the Subcomm. on Administrative Practice and Procedure of the Senate Comm. on the Judiciary, 95th Cong., 2d Sess. (1978); Administrative Procedure Act Amendments of 1976: Hearing S. 796, S. 797, S. 798, S. 799, S. 800, S. 1210, S. 1289, S. 2407, S. 2408, S. 2715, S. 2792, S. 3123, S. 3296, \& S. 3297 Before the Subcomm. on Administrative Practice and Procedure of the Senate Comm. on the Judiciary, 94th Cong., 2d Sess. (1976); Administrative Procedure Act Amendments of 1965: Hearings on S. 1160, S. 1336, S. 1758, S. 1879 Before the Subcomm. on Adininistrative Prac. 
most recent conclusions and unanimously passed S. 1080, the Regulatory Reform Act. ${ }^{58}$ Although S. 1080's companion, H.R. 746, never reached the House floor, ${ }^{59}$ Chadha may have increased the public pressure on Congress to the point that the House may soon consider similar legislation. In fact, S. 1080 and a similar bill, H.R. 220, were reintroduced in 1983.60

To appraise the merits of these legislative proposals, one must first understand the goals that administrative procedures ought to achieve. Historically, concern about agency bias and unfairness, especially when agencies favor regulated industries and fail to serve the interests of unrepresented or underrepresented consumers and citizens, has been a major stimulus of procedural reform. ${ }^{61}$ Evolving notions of fairness, fueled by the changing role of the administrative state in providing essential goods and services, continue to form the basis of broad critiques of agency behavior.62 In addition, agency procedures should be designed to determine accurately the facts necessary to implement statutes. Fairness and accuracy are interrelated, because techniques for ensuring fairness-adequate notice and the opportunity to participate meaningfully im proceedings affecting one's interests-will also ensure accuracy. ${ }^{63}$ Actually, accuracy inay be the primary value. If we possessed a perfect technique for accurate fact finding that required no party participation, it is possible that our interests in fairness would be completely vimdicated. Until such a process is devised, however, fair procedures usually advance the goal of accuracy and perhaps other goals as well.64 Finally, one ought to be concerned about procedural

tice and Procedure of the Senate Comm. on the Judiciary, 89th Cong., Ist Sess. (1965); Administrative Procedure Act Amendments of 1964: Hearings on S. 1663 Before the Subcomm. on Administrative Practice and Procedure of the Senate Comm. on the Judiciary, 88th Cong., 2d Sess. (1964).

58. S. 1080, 97th Cong., 2d Sess., 128 Cong. Rec. S2713 (daily ed. March 24, 1982).

59. H.R. 746, 97th Cong., 2d Sess. (as amended), reprinted in H.R. REP. No. 435, 97th Cong., 2d Sess. 1 (1982).

60. H.R. 220, 98th Cong., 1st Sess., 129 Cong. Rec. H45 (daily ed. Jan. 3, 1983).

61. See Stewart, supra note 34, at 1681-88; Weisbrod, Problems of Enhancing the Public Interest, in Public Interest LaW 30, 31-40 (B. Weisbrod ed. 1978); see also Wong Yang Sung v. McGrath, 339 U.S. 33, 36 (1950)(concern over agency partiality led to passage of the APA); Verkuil, The Emerging Concept of Administrative Procedure, 78 Colum. L. Rev. 258, 262 (1978).

62. See supra notes $46-47$ and accompanying text.

63. "No better mstrument lias been devised for arriving at truth than to give a person in jeopardy of serious loss notice of the case against him and opportunity to meet it." Joint AntiFascist Comm. v. McGratl, 341 U.S. 123, $171-72$ (1951) (Frankfurter, J., concurring).

64. Fairness, signifying a concern to allow participation in agency processes affecting one's hife, has also been said to rest on several values not inextricably related to the concern for accuracy. Participation may be a form of political involvement that gathers its worth not from any factual information supplied to the proceedings but from its demonstration of concern and interest 
efficiency, defined as the low-cost resolution of the business before the agency. Other things being equal, agencies should prefer procedures that are speedier, simpler, and less costly.

Various expressions of these criteria-fairness, accuracy, and procedural efficiency-recur throughout the debate over appropriate administrative procedures. ${ }^{65}$ There is obvious tension among them;

in the outcone. See Michelman, The Supreme Court and Litigation Access Fees: The Right to Protect One's Rights-Part I, 1973 DukE L.J. 1153, 1174-75. Participation also has been thought to act as a spine-stiffener for agency officials, thus forestalling the more outrageous incidents of regulatory capture and producing decisions more consistent with the statutory design. Cramton, The Why, Where and How of Broadened Public Participation in the Administrative Process, 60 GEo. L.J. 525, 527-32 (1972); Crainton, A Comment on Trial-Type Hearing in Nuclear Power Plant Siling, 58 VA. L. REv. 585, 591-93 (1972) [hereinafter citcd as Nuclear Plant Siting]. This interest in producing decisious consistent with the statutory design might, of course, be considercd a variant of adninistrative accuracy, although it is more complex. A desire for increased participation may also be implicated in the admouition that each individual be treated with a certain dignity and respect, including the dignity of being permittcd to state his case. A number of commentators have tried to explain and justify dignitary values in adininistrative law. See, e.g., Mashaw, Administraive Due Process: The Search for a Dignilary Theory, 61 B.U.L. REv. 885 (1981); Mashaw, The Supreme Court's Due Process Calculus for Administrative Adjudication in Mathews v. Eldridge: Three Factors in Search of a Theory of Value, 44 U. CHI. L. REv. 28 (1976); Michelman, Formal and Associational Aims in Procedural Duc Process in Due Process in Nomos XVIII 126 (1977).

65. Similar concepts shine through despite varying terminologies. Professor Vcrkuil speaks of the goals of procedure as "fairness, efficiency and satisfaction," Verkuil, supra note 61, at 280, with our sense of accuracy being subsumed under his category of fairncss, see id. at 279. Satisfaction seeins dependent on fairness, both in its accuracy-related role and in reflecting some of the nonaccuracy-related norms described supra note 64. Presumably Verkuil's sense is not that of subjective happiness in the outcome, which would be too much to expect of a regulatory system. Rather, the notion is more appropriately a test of procedures from the vantage point of one not immediately engaged in the substantive tug-of-war. Its affinity to fairness can thus be underscored by noting its similarity to Rawls's idea of justice as fairness, which appeals to an evaluation detached from the immediate preferences and passions of the moinent. See J. RAwLS, A THEORY OF JusTiCE 11-22 (1971); see also Michelman, Property, Utility, and Fairness: Comments on the Ethical Foundations of "Just Compensation" Law, 80 HARV. L. REv. 1165, 1221 (1967)(applying the fairness idea to just compensation problems). Professor Crainton speaks of accuracy, efficiency, and acceptability. Cramton, Nuclear Power Plant Siting, supra note 64, at 592-93 (1972). Acccptability takes much the same cast we have given to Verkuil's satisfaction. See id. at 593. Professor Mashaw describes the appropriate goals as accuracy, fairness, and timelimess. Mashaw, The Management Side of Due Process: Somc Theoretical and Litigation Notes on the Assurance of Accuracy, Fairness and Timeliness in the Adjudication of Social Welfare Claims, 59 CORNELL L. REv. 772, 774-76 (1974). Timeliness is an aspect of efficiency, and we believe the more general term more appropriate, because it may be acceptable to trade off timeliness for other ingredients of efficicncy, such as cost.

The Supreme Court's current approach to due process adjudication builds on the three factors set out in Mathews v. Eldridge, 424 U.S. 319, 336 (1976):

[F]irst, the private interest that will be affected by the official action; second, the risk of an erroneous deprivation of such interest through the procedures used, and the probable values, if any, of additional or substitute proccdural safeguards; and finally, the Government's interest, including the function involved and the fiscal and administrative burdens that the additional or substitute procedural requisites would entail.

As it stands, this "test" is incomplete as a statement of what values are to be served by the due process evaluation. Accuracy and efficiency concerns are inplicated by the second and third factors, but no content is provided for the item of "private imterest," and the suggestion of the quoted 
honest disagreements can arise about whether particular procedures define and achieve an appropriate mix. Nevertheless, as goals of a procedural system, these three criteria are consistent with what we shall call the internal view of administrative procedure. Viewing procedure internally simply means viewing procedure as serving the goals of fairness, accuracy, and efficiency-goals that can be defined independently of the substantive content of the legislation being implemented and the rule eventually formulated. The social importance of the goals in any particular case will depend heavily on the significance of the underlying substantive pohicies that the procedures implement, but proponents of the internal view see substantive policy formation and procedural systeins design as two logically separate functions. Such an internal perspective greatly influenced Congress's search for generic procedures for agencies and led to the eventual passage of the APA. ${ }^{66}$

language is that "governmental interest" nnay include features in addition to efficiency. As to these, the test tells us generally what to look at, but neither how to value it nor how to be more precise about what we see. The Court has consistently held that one ingredient of due process is an impartial fact-finder, see Tumey v. Ohio, 273 U.S. 510,531 (1927); but see Arnett v. Kennedy, 416 U.S. 134, 158 (1974)(affirming employee discharge for defamation via procedures under which supervisor who was the target of employee's statement made the discharge determination); the Mathews test must either assume that this aspect of fairness is an independent requirenent of due process or capture it in the expanse of the "private interest."

Beyond this ininimal fairness content, subsequent decisions strongly suggest that the idea of private interest coincides with the utility or welfare importance of the private stake in the outcome, with no collateral dignitary interests present. For example, in Dixon v. Love, 431 U.S. 105 (1977), the Court affirmed a summary revocation of a truck driver's license without a hearing, finding that the petitioner's plea for a hearing amounted to nothing more than seeking an opportunity to argue for leniency. "Such an appearance might make the licensee feel that he has received more personal attention, but it would not serve to protect any substantive rights." Id. at 114 . Because the Court also found that no accuracy interest was served by the desired hearing, the state agency's denial of the hearing was proper. Id. The result leaves scant room for any "dignitary" or "process values." See supra note 64.

66. Professor Verkuil has proposed that a concern over "procedural tyranny" provides a thread along which to trace the movement toward adoption of the APA. This tyranny arose when government attempted to displace judicial tribunals, with their distinctive and trans-substantive procedures, by using administrative agencies to inake important decisions regulating private behavior. Verkuil, supra note 61 , at 262. Although many people opposed on the merits the New Deal programs and other regulatory intrusions into the private sphere, there was a consensus that "general procedural guides in rulemaking and adjudication would be adequate to assure fairness"; this consensus facilitated passage of the APA. Id. at 279. Without some faith in the legitimacy of isolating procedure from substantive law, the belief that generic procedural legislation alone could ensure fairness-or any other significant value-would be impossible. Precisely this belief reinforced the sense of accomplishment that buoyed proponents of the APA, who treated the statute as a "comprehensive charter of private liberty and a solemn undertaking of official fairness." McCarran, Foreword to Administrative Procedure Act: Legislative History, S. Doc. No. 248, 79th Cong., 2d Sess. iii (1946). 
2. Procedure Unimportant. Although proponents of the internal view regard substantive policy and procedure as independent factors in the administrative process, they regard both as important factors. Our working assumption, as well, has been that procedure is important, cspecially given that procedure is a ineans to channel agency discretion. Before distinguishing our view froin the internal one, however, we should note that some would dissent from that assumption. For some, procedure is insignificant and ineffectual in the face of substance; in fact, administration is all substance. Under this view, procedures are but hurdles to be cleared on the way to achieving a goal the agency has otherwise determined. Concededly, anyone with much regulatory experience can recall instances in which the participants in official rulemaking hearings tacitly understood that they were inerely creating a record to support a decision made elsewhere. It is against this background, for instance, that Professor Sax has pessnnistically opined that "the emphasis on the redemptive quality of procedural reform is about nine parts myth and one part coconut oil." 67

This pessimism, however, fails to distinguish between instances of procedural inefficacy and the underlying tendencies of procedure to influence results in particular directions. These tendencies may be subtle or difficult to trace and their impact on specific cases inay be negligible. They are real forces nevertheless, and atteinpts to gauge the decisionaltering effects of procedural refornns across a broad range of agency actions have noted the concrete changes such forces produce. For example, the Council on Environmental Quality conducted a major review of the National Environmental Policy Act-the specific focus of Professor Sax's pessimism-and concluded that "environmental assessment and impact statements have substantially improved government decision over the past six years." 68 More generally, procedures create

67. Sax, The Unhappy Truth About NEPA, 26 OKLA. L. Rev. 239, 239 (1973).

68. Council on ENVIRonmental Quality, Environmental IMPaCt STATEMEnTs: AN ANALYSIS OF SIX Years' EXPERIENCE by SEVENTY Federal AgenCies 2 (1976). A later, more focused study conducted by the EPA reported that NEPA procedures resulted in at least one major positive change in the design of 50 out of 51 waste water treatment facilities and 9 out of 9 coal-fired power plants reviewed. COUNCIL ON ENVIRONMENTAL QUALITY, ENVIRONMENTAL QUALITY-1980 371-72 (1980); see also Rodgers, $A$ Hard Look at Vermont Yankee: Environmental Law Under Close Scrutiny, 67 GEo. L.J. 699, 710 (1979)("even though NEPA is 'essentially procedural,' the procedural decisions have had a way of working substantive modifications of agency action"). Earher in the 1970's, Professor Stewart was more skeptical, see Stewart, supra note 34 at 1780 , but he qualified his conclusion by noting that "there is a pressing need for rigorous empirical study of the effects in agency decisions of procedural requirements such as those fashioned by the courts on the basis of NEPA." Id. at 1780 n.526. Although the Council on Environmental Quality's (CEQ) findings may not be "rigorous," they do support the conclusion that procedures do make a difference. For an effort to analyze the organizational, structural consequences of NEPA, 
opportunities for strategic behavior by interested parties; they increase or decrease access and leverage by different groups, coalitions, or affected parties, and they institutionalize tendencies favoring certain kinds of results over others. All these influences can be translated into social consequences. ${ }^{69}$ Because procedures act only indirectly on agency work products, there will always be potential for actions defying the rules of the game, but to argue that procedures never constrain, channel, or direct work products in desirable ways is wrong.

\section{B. The Social Consequences View of Procedure.}

Lying between the internal view's substance-procedure dichotomy and the pessimistic disinissal of procedure as an unimportant factor in

perhaps the most important mechanism through which NEPA influences substance, see CoUNCIL ON ENVIRONMENTAL QUALITY, NEPA In ACTION: ENVIRONMENTAL OFFICES IN NiNETEEN FedERAL AGENCIES (1981). See also Cramton \& Berg, On Leading a Horse to Water: NEPA and the Federal Bureaucracy, 71 Mich. L. REv. 511, 536 (1973)(NEPA can place helpful pressure on agencies).

69. NEPA, for example, aims at producing better informed, and hence different, decisions by forcing administrative agencies to consider the environmental consequences of their actions. The Act has been attacked for merely imposing paperwork burdens and delays, creating procedural traps for unwary and hostile agencies and imterested parties, and being entirely ineffective in altering agency policies or decisions, thus not getting at the "real problem." See, e.g., Fairfax, $A$ Disaster in the Environmental Movement, 99 ScI. 743 (1978); Sax, The (Unhappy) Truth About NEPA, 26 OKLA. L. REv. 239, 248 (1973). By conceding that NEPA may liave tliese effects, liowever, these criticisms acknowledge at least some validity to the social consequences model, because delays reduce tlie rate of agency output, and paperwork burdens increase costs of participation. Botls of these consequences have measurable impacts on the world of private conduct. If certain dains are built more slowly, opponents have additional time in which to enjoy a world without dams, or to organize more effectively to prevent their construction. By changing the procedures of agency decisionmaking, NEPA thus causes some change in the agency work product. It may be that critics from certain ideological or normative perspectives think that those consequences are bad and want to criticize NEPA on that ground, but the normative point is distinct from the descriptive one, which the social consequences inodel attempts to explicate.

Even beyond the delay (which after all may be only transitional, fading away once the agency learns the ropes of procedural compliance) and beyond the increased costs of participation, NEPA affects the decisions the agency makes, the yes or no judgments on approvals of permits, the substantive provisions tlee agency puts into leases of federally owned land, and other such matters. In the short run, any organization with policy perspectives of its own will inevitably view with hostility and resistance external impositions designed, with malice aforethought, to alter those perspectives. They will, in other words, view those procedures as hurdles, and may for a time try to circumvent or ignore them. Gross disregard of procedural requirements is embarrassing and illegal for an agency, however, and even grudging compliance has dynamic effects on organizations. Individuals must be hired, or retramed, to respond to the directive to consider environmental costs. Those individuals becone advocates for their disciplines. New groups of interested parties and expert witnesses must be listened to and their arguments at least comprehended, if not embraced. The contents of the administrative record will change to include more systematic and complete recognition of environmental problems, thus providing arguing points for advocates within the agency. All of these structural and process changes translate into different agency decisions. See supra note 68 . 
administration, a third perspective assesses agency procedures and procedural reforms in terms of the substantive content and effects of the resulting agency work product. This viewpoint inight be called social rather than internal because it focuses on the social impact that the administrative apparatus will have on regulated individuals and groups. It does not succumb to the view that procedure is meaningless, nor does it assert that procedure can be studied as an isolated discipline. Rather, while the social perspective does not deny the internal view's validity, it does challenge its sufficiency. ${ }^{70}$

70. See, e.g., Stewart \& Sunnstein, Public Programs and Private Rights, 95 Harv. L. Rev. 1193, 1221 (1982)(“As both an analytical and a practical matter, the procedures for implementing a regulatory program cannot be separated from its substance."). Several reasons can be advanced to explain, at least partially, why the internal view proves so enduring, despite its inadequacies. First, insofar as analysis of administrative procedure concentrates on generic procedural legislation, namely the APA and proposals to change it, the inquiry strongly reinforces the attractiveness of the procedure-substance separation of the internal perspective, because it is almost impossible to abstract from specific agency mandates and procedures, which is what thinking generically demands, without beginning to think about "procedure" in isolation from any particular substantive statutory regime.

Just as significantly, separatimg procedure and substance for analytic purposes coincides with a deeply ingramed image of the proper division of responsibility within our representative democracy. In that image, the legislature controls the selection of substantive mandates, making the basic policy choices necessary to resolve questions of substantive value conflicts. See, e.g., Stewart, supra note 34, at 1671-76 (describing this as the "traditional model"). It is not the only political model in the American heritage, however. See, e.g., Michelman, Political Markets and Community Self-Determination, 53 IND. L.J. 145, 187-99 (1977-78)(contrasting traditional model with a public interest theory of government, in which courts have a legitimate role in overturning legislative action that is contrary to basic public values). Of course, given the complexity of many problems and the world in which their solutions must be implemented, the legislature inevitably delegates the implementation of its choices to administrative agencies. Yet, since those agencies are not supposed to be making policy, selections of procedures by which they operate should have as little effect as is possible on the substantive content or consequences of its work, other than to require adherence to the statutory command. The internal view holds this image in focus, while making procedure an important and legitimate object for study. It recognizes that choices of procedure can have an important influence on the effectuation of some values, but it defines those values to be independent of the substantive content of the legislation being inplemented.

The internal perspective also reinforces claims of neutrality and professionalism important to the study of administrative process as a disciplime separate from the study of legislation. The Administrative Conference of the United States' reports, for instance, commonly separate proccdure as an object of study. See, e.g., Boyer, Phase II Report on the Trade Regulation Rulemaking Procedures of the Federal Trade Comm'n, in ADMINISTRATIVE CONFERENCE OF THE UNITED STATES [1980] REPORT AND RECOMMENDATION 33, 64 (1980)("it should be possible to make useful judgments about [procedures] without necessarily having some yardstick to judge the quality or accuracy of the decisions themselves"). Substantive values in liberal democracy are highly controversial, especially in the post-New Deal era which denies the existence of a unitary public interest. Because we have developed no substantive theory to accommodate disputes among substantive values, the forinal resolution of them through legislative choice may be our sole theoretically legitimate method of selection, at least where affirmative constitutional checks on legislative selection are not invoked. The procedural values at stake in designing administrative processes are real and important ones, but their reach and the controversial of methods for vindicating them 
A specific example illuminates the distinction between the social consequences view and the internal view. Section 5 of the Federal Trade Commission Act (FTC Act) ${ }^{71}$ declares unlawful all "unfair methods of competition ... and unfair or deceptive practices in or affecting commerce." Whether the FTC could proinulgate rules to carry out its section 5 enforcement responsibilities remained in some doubt for years. It began issuing rules in the early $1960^{\circ}$ s, and eventually the United States Court of Appeals for the District of Colunibia Circuit approved the practice. ${ }^{72}$ During the pendency of the litigation, however, Congress independently considered the propriety and forn of rulemaking under section 5, and enacted the Magnuson-Moss Warranty Federal Trade Coininission Improventent Act of 1974 (Magnuson-Moss Act). ${ }^{73}$

The Magnuson-Moss Act modified the FTC Act by adding section 18 , which prescribes a unique set of rulenraking procedures to enforce section 5. These procedures build on the infornal rulemaking skeleton of the APA, resulting in a form popularly called "hybrid ruleunaking." Among the most important additions by this hybrid rulenraking to the generic notice and comment process are (1) a requirenent that the FTC hold informal hearings, at which parties nray engage in cross-examination on certain "disputed issues of material fact,"74 (2) a right to make oral presentations, ${ }^{75}$ and (3) a judicial review provision that authorizes courts to set aside a rule if "the Commission's action is not supported by substantial evidence in the rulemaking record ... taken as a whole." 76

These hybrid procedures for the FTC can be supported on two separate grounds. First, they arguably ensure technically accurate and sound rulemaking decisions by providing additional opportunities for contesting parties to probe, dispute, and rebut proposals. Opportunities for public hearings and oral presentations also provide a sense of fair-

are greatly constrained by the premise that the legislature remains the sole repository of the substantive policy making power. If process choices become universally recognized as implicating certain substantive choices not made explicitly by the legislature, procedural battles would become even more contentious, while the study of process changes as a logically independent inquiry would be indicted.

71. Federal Trade Commission Act § 5, 15 U.S.C. \& 45(a)(1) (1982).

72. National Petroleum Refiners Ass'n v. FTC, 482 F.2d 672, 698 (D.C. Cir. 1973), ccrt. denied, 415 U.S. 951 (1974)(the Octane case).

73. Magnuson-Moss Warranty-Federal Trade Coinmission Inproveinent Act., Pub. L. No. 93-637, 88 Stat. 2183 (1975)(codified as amended at 15 U.S.C. \& 57a (1982)) [hereinafter cited as Magnuson-Moss Act].

74. 15 U.S.C. \& $57 \mathrm{a}(\mathrm{c})(2)(\mathrm{B})(1982)$.

75. 15 U.S.C. $\$ 57 \mathrm{a}(\mathrm{C})(2)(\mathrm{A})(1982)$.

76. 15 U.S.C. $\$ 57 \mathrm{a}(\mathrm{e})(3)(1982)$. 
ness by giving potentially affected parties a more satisfying hearing than is accomplished by mailing comments to the regulatory agency. These rationales rest upon the internal view of administrative procedure. They do not depend on any prior assessment of the merits of FTC objectives or policies; they treat accuracy and fairness as desirable ends in themselves.

Second, procedures can also control the freedom of an agency to make decisions, a fact not lost on some proponents of the hybrid form. Concern with controlling the FTC's broad discretion under the admittedly expansive wording of section 5 runs throughout the MagnusonMoss Act's legislative history. Such control could have been accomplished by either narrowing the FTC's substantive mandate or revising its procedures. The Magnuson-Moss Act chose the latter route. ${ }^{77}$ Accurate fact-finding requirements control discretion by directing the agency to develop rules that have firm factual foundations. In addition, the threat of heightened scrutimy through judicial review channels discretion away from speculative decisions stretching the outer limits of delegated authority toward more firmly grounded, less adventurous ones. Elaborate procedures can control discretion by forcing an agency with limited resources to commit a greater proportion of those resources to each rulemaking proceeding, thereby reducing the rate at which the agency can produce rules and the rate at which the attendant social impacts will follow. Thus, an opponent of section 5 might support section 18's hybrid rulemaking procedures as a way to slow down the FTC and render it timid and cautious. ${ }^{78}$

This second ground supporting the hybrid procedures reflects the social view of administrative procedure. Under this view, processes are important only insofar as they induce change in the social impact of the agency's work. In other words, unlike the internal view, the social view is concerned with how procedures affect people in their daily hives. The task of assessing the social consequences of an agency's work is far

77. The Magnuson-Moss Act expanded the FTC's jurisdiction beyond businesses "in commerce" to imclude all busmesses "affecting commerce." See 15 U.S.C. § 45(a)(1) (1982)(as amended by the Magnuson-Moss Act, Pub. L. 93-637, § 201(a), 88 Stat. 2183, 2193 (1975)).

78. The experience of the FTC under the Magnuson-Moss Act demonstrates the efficacy of such a strategy. In the eight Magnuson-Moss rulemaking proceedings that reached the FTC for final action by April 1980, 27 months, on the average, passed from the end of the oral hearing to the first Commission meeting to consider the rule. In the three proceedings that ended with promulgation of a final rule, the average time from the first Commission meeting to consider the rule to publication in the Federal Register was an additional 8.5 months. Admin. Conf. of the U.S. Recommendation 80-1, para. A, 1 C.F.R. $\$ 305.80-1$ (1983). A completed rule easily costs inore than a million dollars, and most likely consumes more than 10,000 man-hours of staff tiune. Boyer, supra note 70, at 120; see also Diver, supra note 41, at 433. 
from straightforward. It requires assessing agency performance over time by, for example, considering the rate at which it performs its work. An agency that acts slowly and on relatively few matters is less likely to generate great numbers of significant social consequences. The cost of participation in the process is another social consequence of an agency's work product. A subtler but no less real attribute of administrative agency performance is its ability to change people's attitudes toward it and its mission. All these factors ${ }^{79}$ contribute to a perspective that evaluates agency procedures only msofar as they alter the social effects of the agency's work product.

In distinguishing the social from the internal viewpoint, we are describing pure forms. No observer of the administrative process may hold either of these viewpoints exclusively. The ambiguity surrounding procedural systems makes it almost impossible to isolate either view. For example, legitimacy is sometimes cited as a value for administrative processes, but it can be a function of one's perception of the fairness of the process employed to reach a decision-an internal view-or a function of the substantive decisions agencies reach-a social view. Most often, legitimacy will mean both. This imprecise language makes categorizing what people say and write about administration difficult, but it also provides a reason to make the distimction. If the social consequences of procedural change are not being fully appreciated, drawing attention to the differences in the two views can sharpen our understanding of the importance of those consequences and can facilitate analysis of the consequences themselves.

The generic nature of the APA, and hence of the proposals to change it, may cause the internal, substance-divorced perspective to echipse the social, outcome-centered perspective on administrative process. A full evaluation of the merits of any procedural reform, including generic reform, however, requires an appreciation of both its internal and social consequences. This point, which seems plain when considering a specific substantive legislative proposal that includes procedural mechanisms, should not be lost when Congress turns its attention to reform of the APA itself.

79. For a more complete statement of the factors relevant to social consequences analysis, see infra Part VI. 


\section{The Effects of Process Reforms Upon Strategy FORMULATION}

\section{A. Rulemaking as a Strategic Game.}

Under the social consequences view, the benefits and costs of process reform must be evaluated in light of the changes they induce in the rules that regulatory agencies issue and the impact those changes have on interested parties. In order to perform this evaluation, one must be able roughly to anticipate the influence procedural change has on rulemaking outputs. This anticipation can be accounphished by viewing the regulatory process as a game participated in by self-interested parties pursuing their own advantage. Because the configurations of parties, process, and substantive law vary from agency to agency, a thorough deployment of this simple game nodel would entail agencyby-agency analysis. Short of such a complete assessment, we can illustrate how the model advances analysis of process reform and draw some conclusions, albeit generalized, about the predictable effects of several reform proposals.

Regulatory agency decisions depend upon the behavior of all participants in the rulemaking process. These participants include the various offices within the agency, reviewing courts, Congress (through oversight and budgets), OMB (through oversight), and intervenors such as individual firms, industry trade associations, environmental organizations, and consumer protection groups. The rules of the game, that is, the rulemaking procedures, define the instruments, such as written comments submitted by private parties, technical reports generated by the agencies, consent decrees sometimes proposed by environmentalists, and regulatory impact analyses prepared by the agencies, that each participant uses to further its own objectives. Because the participants know that the outcome of a rulemaking process depends upon the actions of all the participants, to be successful players must each anticipate both (1) the likely actions and positions taken by the other participants and (2) the changes in each participant's behavior likely to be induced by the actions of the others. Anticipating these two factors requires a strategy for each participant-a set of actions and reactions that the participant will take in light of the likely consequences.

This "rulemaking game" perspective illustrates the difficulty of predicting the full range of effects of a regulatory process reform proposal, especially one so extensive as S. 1080. Process reforms change the rules of the game, requiring each participant to reevaluate both its expectations of other participants' behavior and the likely consequences on the others of its strategies. Therefore, to predict the effects 
of the reform proposal, one must evaluate both the likely changes in strategy and the combimed effects of all changes upon regulatory decisions.

\section{B. Regulatory Impact Analysis: An Example of the Rulemaking Game.}

A specific example of this type of analysis of players' strategy choices based on other players' actions demonstrates the utility of the social consequences model. The imcomplete example that follows is merely illustrative because it concentrates primarily on the actions and reactions of only one player, the agency.

S. 1080 would require that agencies submit regulatory mupact analyses with both their notices of proposed rulemaking and their final rules. ${ }^{80}$ Because Executive Order 12,291 already requires such analysis for major rules promulgated by nonindependent regulatory agencies, we can evaluate the proposed amendment by extrapolating imformation from those agencies that already have complied with the existing requirement. In a recent study of the regulatory analyses performed by agencies durmg 1981, eight individual analyses were singled out to illustrate sigmificant analytical flaws. ${ }^{81}$ Although the study did not attempt to explain the causes of the analyses' defects, many analytical errors were apparent in the eight examples even though the OMB had approved them. This finding suggests that one possible strategic response by regulatory agencies to S. 1080's new analytical requirement might be to perform an after-the-fact analysis that neither affects an agency decision nor provides evidence confiicting with the decision. If the agencies suspect that the OMB and the courts will accept any statement of regulatory impact analysis, no matter how flawed, and if the agencies are satisfied with regulations they are promulgating, then agencies will continue to follow their own agenda for social change despite the procedural reform.

The opposite strategic response would be for the agency to perform high-quality regulatory analyses. An agency might consent to such an approacl for several reasons. First, if the agency wishes to slow down or halt its rate of rulemaking, perhaps because its management is unsympathetic to the agency's mission, then the requirement of

80. S. 1080, §4(a) (amending APA to add § 622(c)(1) and 622 (d)(1)), 128 CoNG. REC. S2713, 2715 (daily ed. March 24, 1982).

81. W.N. Grubb, M. Humphries \& D. Whittington, The Use (and Abuse) of Cost-Benefit Analysis in the Federal Government: The Implementation of Executive Order 12,291 (October 1982)(unpublished inanuscript)(copy on file with authors). 
a regulatory impact analysis statement provides it with a convenient excuse for delay - a ploy that works particularly well when the OMB chooses not to prod the agency. Second, when the OMB insists on strict compliance with the regulatory analysis requirement, the agency has hittle choice but to carry out thorough analyses if it wants to issue any regulations. The agency's best strategy im this case is to devote substantial agency resources to producing a detailed, though somewhat biased, regulatory analysis that will support the agency's own rulemaking preferences. The literature on cost-benefit analysis provides ample guidance on how to "tilt" such studies to support a preferred alternative. ${ }^{82}$ A third alternative explanation involves the reviewing courts. If they, rather than the OMB, were to require strict adherence to the regulatory analysis requirement, then agencies wishing to promulgate any sigmificant regulations would be forced to comply. Finally, the agency may be dominated by economists who believe that allocative efficiency ought to be the mam criterion used for framing regulations. One only need imagime Alfred Kahn or Darius Gaskins as the EPA Administrator to understand how an agency might find virtue in performing meaningful cost-benefit analysis and using it to make decisions. ${ }^{83}$ Whatever the explanation for agencies producing high quality analyses, however, the result is likely to be the same-fewer, but more efficient, regulations.

A third agency response to the regulatory analysis requirement is possible. Rather than either resist or embrace the analytical requirement uniformly, the agency could adopt a strategy of performing high quality analyses on only select regulations. The agency could choose regulations deserving close scrutiny by assessing early in the rulemaking process whether careful analyses are likely to support or undercut the agency's preferred regulatory decision. The agency would devote

82. Although studies of cost-benefit analysis seldom are written explicitly to educate agency personnel as to how they can manipulate such analyses, most do highlight components of such analyses for which there is no unequivocally correct approach (e.g., determining the proper discount rate) or for which determming the correct value is difficult (e.g., deterinining the value of costs or benefits for which there are no close market analogues). For surveys sensitive to such issues in the public policy context, see CosT-Benefit ANALysis AND Water Pollution Policy (H. Peskin \& E. Seskin ed. 1975); Prest and Turvey, Cost-Benefit Analysis: A Survey, 75 EcoN. J. 683 (1975)). These studies provide clear roadmaps for an analyst inclined to influence the results of the analysis by the assumptions and values he chooses to use.

83. Kahn and Gaskins, both economists, and both one-time heads of independent regulatory agencies that underwent significant deregulation during their tenures (Kahn at the Civil Acronautics Board; Gaskins at the Interstate Commerce Commission), strongly advocate cost-benefit analysis in assessing the merits of regulation. See Gaskins \& Voytko, Managing the Transition 10 Deregulation, LAW \& CONTEMP. ProBS., Winter 1981, at 9; Kahn, Applications of Economics to an Imperfect World, 69 AMER. ECON. Rev. 1 (1979). 
its limited resources toward analysis of those regulations most likely to be supported by thorough analyses, or, alternatively, toward those regulations most likely to be highly criticized in the rulemaking process, especially when those criticisms are supported by other thorough analyses. Of course, if the agency lacks "control" over the outcome of any such cffort, it runs the risk that its own analysis will be used against it. Even if the agency suppresses publication of the contrary analysis, the agency is in an awkward position as long as other participants know the contrary analysis exists. ${ }^{84}$ An agency may also find useful this strategy of selective excellence im regulatory analysis when it can anticipate the quality of analysis likely to be offered by the other participants in the rulemaking process. The agency can then incorporate these expectations into its decisions to allocate analytical effort among various regulations. For example, if, in a major environmental rulemaking involving the steel industry, both the American Iron and Steel Institute and the Environmental Defense Fund present their own thorough costbenefit analyses, then the EPA might want to allocate its resources to an analysis of the discrepancies in the two studies, rather than mitiate an independent, all-inclusive study.

Note that the choice of which of these three possible agency strategies to adopt-minimal analysis, exhaustive analysis, or selective analysis-depends both on the agency's substantive preferences and on the hikely behavior of other participants in the process. To accurately predict the net results of the regulatory analysis requirenent, several furthcr steps must be taken. The strategy choices available to each of these other participants would have to be identified and then related to the behavior of all other participants. Finally, some solution concept must be apphied to find a set of strategies with consistent expectations and the dynamics of the parties' strategy formulation and revision must be explored to determine what outcome is likely.

\section{Evaluation Criteria}

As already explained, regulatory process reforms will affect the strategies of rulemaking participants, who in turn collectively can determine how agency decisions, the outcomes of the process, change. To judge whether the reforms are socially desirable, however, we need to

84. William Ahern, Cliairman of the California Coastal Commission, tells a deliglitful story about why lie would never lire an outside consultant precisely because of this control problem. See H. Kunreutler, J. Linnerootl \& R. Starnes, Liquified Energy Gas (LEG) Facility Siting: International Comparisons, Proceedings of the IIASA Task Force Meeting, Sept. 23-26, 1980, International Institute for Applied Systems Analysis, Laxenburg, Austria (unpublislied manuscript) (on file with autliors). 
proceed one step further. The outcomes, imfluenced as they are by the process reforms, must be evaluated. We propose six criteria without specifying how the mevitable trade-offs are to be made among them and how each affects the others. Two of the criteria, economic efficiency and distributional equity, are more basic than several others: delay, rate of rulemaking, and costs of participation. The latter are, to a certain extent, coinponents of the former because they create efficiency or distributional effects. The sixth criterion, the legitimacy of rules, stands imdependently of the others.

\section{A. Economic Efficiency.}

The specific regulatory process used to translate a statute into regulations affects the levels of the standards, or, more generally, the stringency of the rules. For example, judging from the negative reaction of environmental and consumer groups to the use of cost-benefit analysis as a decisionmaking tool, and from support by business groups for such analysis, a process change requiring the use of cost-benefit analysis will generally result im less stringent standards for industry. More stringent standards might emerge, however, if Congress required agencies to produce better technical data in support of the regulations most frequently challenged in court by industry groups; the improved data would lead to fewer court remands of agency decisions. More stringent rules might also result if agencies provided funds to public participants who could provide corroborative evidence in support of the agency's official position, agam because remand would be less likely. By altermg the stringency of regulations, process changes alter the efficiency with which society's resources are used. Thus, some rules or standards can be judged to be superior to others by deterniming the extent to which they increase efficiency. The cost-benefit analysis procedural requirement, for example, will lead to more efficient regulations.

\section{B. Distributional Equity.}

Because process changes alter the stringency of regulations, they also can redistribute wealth, a desirable or undesirable result dependmg on one's sense of distributional equity. Distributional equity is, however, a more subjective criterion than economic efficiency; it reflects individual and group judgments about the fairness of the distribution of economic resources. By imfluencing the stringency of regulations, process changes cause some parties to gam or lose at the expense or benefit of others. For example, EPA's recently promulgated visibility standards for controlling air pollution in national parks pro- 
tect scenic views for park visitors, ${ }^{85}$ but impose compliance costs upon electric utilities and smelters located near the parks. Because the visibility standards apply primarily to new power plants and exempt niany existimg plants, they favor existing plants over new ones. ${ }^{86}$ The standards may also have a disproportionate impact on companies operating in certam geographical regions, such as the western states, where national parks protected by the standard abound. Other standards, such as those requiring special scrubbers in power plants that use high sulfur coal, may impose disproportionate costs on compames and consuniers in the nortlieastern states. ${ }^{87}$

\section{Delay.}

Delay in the promulgation and enforcement of regulations extends the length of time between the passage of enabling legislation and the accrual of its benefits and costs. For example, much of the delay in nuclear power plant construction is caused by the regulatory requirements of the Nuclear Regulatory Comimssion (NRC). One proposed procedural reform would allow the NRC to approve standardized plant designs and reduce these delays. ${ }^{88}$ The Food and Drug Administration is also frequently criticized for its slow review of new drug applications. The agency is currently attempting to reduce regulatory lag by adoptmg procedures such as accepting foreign data on the effects of the drugs under review. ${ }^{89}$ The Securities and Exchange Cominission's experimental shelf registration program is similarly designed to ease regulatory delays; it reduces the time and cost required for a firm to issue new securities. ${ }^{90}$

85. 40 C.F.R. $\$ \S 51,300-307$ (1983); see also Protecting Visibility Under the Clean Air Act: EPA Establishes Modest "Phase" I Program, 11 ENVTL L. REP. (ENVTL. L. INST.) 10,053 (1981).

86. The visibihty regulations require use of "best available retrofit technology" (BART) on existing sources or an existing facility when the inpaired visibility "is reasonably attributable to" that facility. 40 C.F.R. $\$ 51.302$ (c)(4)(i) (1982). This means that no expensive BART will be necessary if the impaired visibility is the result of a "widespread, regionally lomogeneous haze from a inultitude of sources." 45 Fed. Reg. 80,084, 80,085 (1980).

87. 40 C.F.R. $\S 60.43$ (a) (1983). The power plant regulations are exhaustively analyzed in Sierra Club v. Costle, 657 F.2d 298 (D.C. Cir. 1981). See supra note 56.

88. See, e.g., ENERGY Users ReP. (BNA), No. 433 at 1668 (Nov. 26, 1981)(NRC task force formed to study one-step licensing, standardization and early site reviews to speed up licensing).

89. See Food and Drug Administration, Proposed Rule-New Drug and Antibiotic Regulations, 47 Fed. Reg. 46,622, 46,642-44 (1982).

90. 17 C.F.R. § 230.415 (1983). 


\section{Rate of Rulemaking.}

Procedural reforms can also affect the total number of rules an agency promulgates each year. Given fixed-and for some agencies declining-budgets, regulatory process changes that require an agency to devote more resources and more time to each regulation necessarily result in fewer new regulations and less review of existing rules. The national park visibility standards are mandated by only one of over a hundred sections in the 1977 Clean Air Act Amendments.91 Agency resources employed in implementing the visibility provisions were unavailable to implement other, perhaps inore important, sections of the Act.

The Reagan Administration takes pride in its reduction of the number of regulations printed in the Federal Register since it took office. The decline is to some extent attributable to the procedural requirements imposed by Executive Order 12,291.92 Certainly, codifying several features of Executive Order 12,291, as in S. 1080, would continue to reduce the rate of federal rulennaking. The social desirability of this reduction depends upon whether the delayed or cancelled regulations would have increased efficiency or redistributed benefits to particular parties. Judge Scalia noted the irony that some industrial advocates of weaker standards prefer an increased rate of rulemaking so that sympathetic agencies can more quickly issue those weaker rules. ${ }^{93}$

\section{E. Costs of Participation.}

Procedural requirements affect the costs of all parties participating in the regulatory process. For example, increased analytical requirements and a more extensive use of hearings would impose higher costs on the agencies and on parties who inust hire representatives to appear on their behalf. Although only suggestive, some statistics from environmental organizations detailing the costs of participatimg im regulatory and judicial proceedings illustrate the point. The Sierra Club spent $\$ 2.31$ million in fiscal year 1979 to study and influence public policy, twenty-eight percent of the club's budget. The Environmental Defense Fund, a public interest law firm founded in 1967, was spending $\$ 2.6$ million per year by 1982 . The Natural Resources Defense Council, a public interest law firm established in 1969, was spending

91. 42 U.S.C. $\$ 7491$ (Supp. V 1981).

92. Exec. Order No. 12,291, 3 C.F.R. 127 (1982).

93. Scalia, Regulatory Reform-The Game Has Changed, REG., Jan.-Feb. 1981, at 13. 
$\$ 0.93$ million of its $\$ 1.37$ million budget on litigation by fiscal year 1975.94

Some procedures can impose significant costs on Congress and the $\mathrm{OMB}$, too. For example, the House of Representatives responded to the Chadha decision by including a congressional review procedure in the Consumer Products Safety Commission's (CPSC) reauthorization bill. ${ }^{95}$ If expanded to many other agencies, ${ }^{96}$ this new procedure will pressure Congress to review, subject to the constitutional restrictions enforced in Chadha, every regulation that CPSC or another agency promulgates. Unless Congressmen are willing to substitute regulatory issues for other issues on their agendas, which would impose higher costs on congressional decisionmaking, they will be forced to expand their staffs to gain the expertise and capability for evaluating the requests for reconsideration of agency decisions that will be made by the "losing" participants in the rulemaking process.

\section{F. Legitimacy of Rules.}

Finally, much of the interest in regulatory process reform may be due to the fact that agency processes affect the legitimacy of agency rules. Parties who voice their views within a well-defined process are more apt to accept the legitimacy of an agency decision, even if they do not influence the stringency of the regulations. Parties that have had the opportunity to present their views to the agency may be less likely to seek judicial review, and instead may devote more resources and effort to find acceptable ways to comply with the agency decision. There may also be some value in participation per se. After all, many attorneys enjoy playing the game.

94. These figures are cited in Downing \& Brady, The Role of Citizen Interest Group in Environmental Policy Formulation, in 6 NONPROFIT FIRMS IN A THREE SECTOR ECONOMY, COUPE Papers on Public Economics 73-77 (Michelle White, ed. 1981).

95. Immediately after Chadha, the House approved an amendment introduced by Represenative Levitas that would prevent substantive CPSC rules from becoming law until Congress approved the rule by joint resolution and either the President signed the joint resolution or Congress overrode the veto. 129 CoNG. REC. H4773-74, 4781 (daily ed. June 29, 1983). The Levitas amendment eviscerates CPSC rulemaking authority. The House also approved an amendment imtroduced by Representative Waxman providing a ninety day period before CPSC rules could become effective, during which time a rule could be blocked by a joint resolution and a presidential signature or congressional veto override. H.R. 2668, 98th Cong., 1st Sess., 129 CoNG. REC. H4771, 4783-84 (1983). The bill is currently in conference with a Senate version, S. 861, 98th Cong., 1st Sess., 129 CoNG. REC. H4782-83 (1983), that does not contain a provision comparable to either amendment.

96. On July 20, 1983, Senators Boren, Grassley, Kasten, and Levin introduced legislation similar to the Waxman amendment to the CPSC authorization bill, see supra note 95 , that would apply to all federal agency rules. See S. 1650, 98th Cong., 1st Sess., 129 CoNG. REC. S10.473-77 (daily ed. July 20, 1983). 


\section{APPLYING THE MODEL}

Having described a inethod for analyzing the impact of procedural reforms on the outcome of regulatory decisions and developed a set of criteria for evaluating those impacts, we now analyze several contemporary regulatory reform proposals. We will examine: (1) the requirement that major rules be supported by regulatory impact analyses; and (2) OMB oversight of agency rulemaking. Both of these proposals are regularly offered and debated as means to improve regulation, ${ }^{97}$ and they comprise part of the core of the latest reform bill, S. 1080.

These reforms continue the post-New Deal effort to control administrative discretion through a program of internal agency constramts and external review. The reforms would not remove agency discretion, but would merely recast its modes of expression. As we noted earlier, the only thorough way to anticipate the effects of elements of a reform package such as S. 1080 on the various regulatory participants is to examine the relationships between the particular regulatory statutes, administrative agencies, and interested parties. For example, a reform's effects on deceptive practices rulemaking at the FTC would differ from its effects on the effluent guideline procedures at the EPA. Nevertheless, it is possible to outline some generic effects of certam reform proposals, and thereby illustrate the type of analysis required to understand the social consequences of such reforms.

\section{A. Regulatory Impact Analysis.}

One of the provisions of S. 1080 would require agencies to perform a regulatory impact analysis of any rule with an annual effect on the economy of $\$ 100$ million or more. ${ }^{98}$ The methodology for regulatory analysis required by the bill mirrors the provisions of Executive Order 12,291, signed by President Reagan early in his term of office. S. 1080 would require an agency to publish a preliminary analysis along with the notice of the proposed rule and a final analysis to accompany the

97. Presidents Ford, Carter, and Reagan all have imposed regulatory analysis on executive agencies, indicating their respective administrations' belief that such analysis inproves regulation. See Exec. Order 11,821, 3 C.F.R. 926 (1971-75 Comp.), extended and name changed by Excc. Order 11,949, 3 C.F.R. 161 (1977)(Ford); Exec. Order 12,044, 3 C.F.R. 152 (1979) (Carter); Exec. Order 12,291 3 C.F.R. 127 (1982)(Reagan); see also SENATE COMM. ON THE JUDICIARY, S. REP. No. 97-284, 97th Cong., Ist Sess. 64-93 (1981)(summarizing commcntary on regulatory analysis and OMB oversight); R. LITAN \& R. Nordhaus, Reforming Federal Regulation 136 (1983)(regulatory analysis essential to sound regulation); L. WHITE, REFORMING REgulation: PROCESSES AND PROBLEMS 13-26 (1981)(summarizing regulatory impact analysis reform efforts).

98. S. $1080, \S 4($ a)(amending APA to add $\S \S 622(\mathrm{c})(\mathrm{l})$ and $622(\mathrm{~d})(1)$ ), 128 CoNG. REC. S2713, 2715 (daily ed. March 24, 1982). 
rule as promulgated. The analysis must identify the benefits and the costs of the rule, a description of alternatives, and an explanation by the agency of why it believes the benefits will justify the costs and why the rule it proposes will be more cost-effective than the alternatives, ${ }^{99}$ subject to the requirements of the agency's enabling statute. The regulatory analysis requirement is clearly meant to address the reality of agency discretion by forcing the agency to articulate its rationale for choosing a particular rule from among permissible alternatives.

In assessing this reform, consider first the evaluation criteria of economic efficiency. In principle, regulatory mipact analyses should improve the efficiency of major regulations. Whether that result ensues, however, will depend on the attempts by the regulatory participants to secure a rule favorable to their own positions-attempts made possible by the many unresolved issues that lie behind any formalized cost-benefit or impact analysis requirement. The battles that result will be fierce in those cases where substantial power shifts or strategic advantages hang on the outcomes. For an example of current interest, we explore the debate between the OMB and the EPA over the use of costeffectiveness techniques in establishing regulatory standards for the removal of pollutants under the various statutes admimistered by the EPA.

The 1977 Clean Water Act imposed a cost-reasonableness test for those EPA industrial water pollution standards that had previously been based upon the "best available technology economically achievable" (BAT). ${ }^{100}$ BAT standards meeting the new test were to be redesignated as "best conventional pollutant control technology" (BCT) standards; BAT standards failing the cost-reasonableness test were to be weakened to ineet it. ${ }^{101}$ The Clean Water Act's cost-reasonableness test required that the costs to industry of abating water pollution be "reasonable" relative to the cost of abatement by privately owned treatment works (POTWs). Since 1977, the EPA has struggled with this vague mandate. After several years of ruleunaking activity involvmg the EPA, the Carter Administration's Regulatory Analysis Review Group, the OMB, and many industrial intervenors, the costreasonableness test finally has been defined to require that the marginal cost of industrial BCT standards not exceed the marginal cost of POTW standards. ${ }^{102}$

99. Id.

100. 33 U.S.C. $\$ 1314$ (b)(4)(B) (Supp. V 1981).

101. Id.

102. 43 Fed. Reg. 37,591-95 (1978). The definition was subsequently upheld. See American Paper Inst. v. EPA, 660 F.2d 954, 961-65 (4th Cir. 1981). 
Under a variety of simplifying assumptions, such as that the benefits of pollution removal not be systematically related to the location of discharges from different industry categories, it can be shown that to the extent future BCT standards are based on the POTW benchmark marginal cost, they will lead to more efficient water pollution standards.

The OMB would like to make air pollution regulations more efficient too. Using its authority under Executive Order 12,291, the OMB argues, in summary, that the EPA should establish a benchmark marginal cost target for each air pollutant, and then write standards for the various industry groups and subgroups that are consistent with those benchmarks and therefore cost-effective. ${ }^{103}$

Putting aside the issue of whether the specific statutes the EPA implements can be construed to tolerate such an approach, the use of such benchmarks for setting either water or air standards will have substantial consequences on the way the EPA conducts its business. This approach introduces a decisionmaking criterion that has the potential to dominate all others in the standard-setting process. It will greatly reduce the flexibility that the EPA currently has in setting standards on an industry-by-industry basis because the agency currently feels little need to base standards on comparative analyses of the standards it has set for like pollutants in other industries. Any agency interested in maintaming its ability to set regulations on a case-by-case basis, and hence its power either to adapt readily to new information and analyses or to maintain bargaining leverage with the various groups with which it deals, would be inclined to resist such a standardized approach, as some groups in the EPA have done.

A single benchmark figure for each water or air pollutant will, furthermore, acquire a gravitational force making deviations from it very difficult. Once such a margimal cost target has been established as appropriate in a smgle case, minimal standards of rationality would require ample justification for failing to einploy the benchmark in all cases. Plausible arguments might be made for treating polluters with difficult probleins differently on the basis of their different abatement benefit schedules, but such benefit calculations are both difficult and controversial, and would additionally require the EPA to give idiosyncratic polluters a prominence in the regulatory process that they have so far avoided. In any event, the burden for justifying deviations from

103. Interview with Christopher DeMuth, 13 ENv'T REP. (BNA), 1574, 1575 (January 14, 1983). 
a standardized norm would fall on the agency, a situation that would further diminish its flexibility.

Consider next another of the criteria for evaluating process reforms, that of distributional equity. Imposition of specific benchmarks for reasonable costs for pollution abatement would have several likely distributional effects. If the OMB wins the battle over employing the device of margimal cost benchmarks for air pollution standards, every indication is that under the current administration the benchmark level that the OMB selects would be lower than that favored by the EPA. With a lower marginal cost target figure, more pollution will result with a concomitant shift in burden from producers to breathers. Within the industry a lower benchmark would likely favor small firms over large ones. Existing standards, which set uniform removal requirements for all firms, favor large firms, which are generally more able than small firms to take advantage of the economies of scale associated with inost sophisticated pollution removal technologies. The result has been a consistent pattern of higher marginal costs for smaller firms under a uniform standard regime. Even im those instances where small and large firms are ruled by different standards, the EPA has apparently not totally compensated for this effect, so that smaller firms' inargmal costs remaim higher. ${ }^{104}$

The current debate between the EPA and the OMB concerns setting effluent and emission standards for specific industries. The use of regulatory impact analysis on the ambient air quality standards that the EPA must set would also have distributional consequences, although to predict their exact nature one must inquire into the scientific and economic data associated with each of the pollutants and pollutant sources that the EPA monitors. Use of benefit analyses will have the effect of tightening the standards for some of the pollutants while loosening them for others, depending on the evidence of benefits and the availability of removal technologies.

Employmg any kind of regulatory analysis will benefit groups with access to relevant data, as well as groups with the computational and analytical skills necessary to perform such analyses. Particularly because many of the assumptions necessary to conduct cost-effectiveness or cost-benefit analyses are controversial, interested parties im regulatory processes employing such techniques will be forced to protect their interests in the regulatory outcomes by monitoring and attempting to

104. W. Magat, A. Krupnick \& W. Harrington, Rules for Making Rules: The Revealed Preference Approach to Understanding Regulatory Agency Behavior, Table $6-4$ (forthcoming 1984). 
influence the analysis process itself. Only groups with the relevant resources and skills will be able to maintain such a vigil and accrue the advantages that accoinpany it. In cases of consumer protection and environmental regulation, for exainple, imdustry groups will have an advantage over consuiner and environmental groups, whose more meager resources will be less able to respond to new analytical requirements. Furthermore, because under most regulatory processes the agency must rely in the first instance on the regulated industry for accurate information, industry groups will continue to enjoy the advantage of their superior familiarity with the relevant data and their ability to disclose information in potentially favorable formats.

Let us move to two additional evaluation criteria for rulemaking reform. In the short term, a shift to cost-effectiveness analysis of the kind conteinplated by the OMB in its dispute with the EPA can only serve to (1) delay rulemaking and hence (2) diminish its rate, assuming no additional agency resources are committed to the process. Whether this shift will produce long-term effects on the delay and the rate of rulemaking will turn heavily on the response of interested parties, the courts, and the agency to the initial benchmarks. If these benchmarks acquire acceptance and legitiniacy and do not generate pressures to diverge froin them, the rate of rulemaking nay increase, as the participants focus more narrowly on the cost data necessary to translate each benchmark into industry-specific rules. If, however, agencies and participants regularly devote serious efforts to justifying departures from the benchmarks through the use of benefit studies that support different marginal cost targets, then the controversial aspects of such studies could prolong the effort to write any individual industry rule, and hence have a long-term dampening effect on the rate of standard setting.

Of the remaining evaluation criteria, the impact of regulatory analysis on the cost of participation in the rulemaking process was addressed above as part of the discussion of the distributional consequences of the procedural reform. The last criteria concerns the legitimacy of the agency process. Whether the results of a cost-effectiveness approach at the EPA acquire greater legitimacy than does the agency's current operation rests on eleinents too contingent to evaluate in this paper. Any change in legitimacy will be influenced by the degree to which observers of the regulatory process consider a given costeffectiveness standard to be consistent with their sense of regulatory fairness; it is not clear, however, how observers will assess the "fair share" of pollution control each industry should bear. Complicating 
the issue further are the effects of the various strategic responses on perceptions of fairness. Even if the principle behind the reforn rings true, the ability of certain participants to influence unduly the regulatory outcomes may undermine the legitimacy of the agency procedures, regardless of any objective change in the results.

\section{B. Office of Management and Budget Oversight.}

Executive oversight has become a major feature of the debate over the design of the rulemaking process since President Carter's 1978 Executive Order $12,044^{105}$ established regulatory review powers for the President's Regulatory Analysis Review Group and the Council on Wage and Price Stability, and President Reagan's 1981 Executive Order $12,291^{106}$ created regulatory review and oversight responsibility for OMB. One cannot evaluate S. 1080's cost-benefit analysis requirements without considering the stage in the regulatory process at which the cost-benefit analysis would occur. President Reagan's version of regulatory analysis subtly shifted the prior administration's approach. Under Executive Order 12,291, the OMB must approve in advance all initial regulation proposals. Under President Carter's version, the Regulatory Analysis Review Group and the Council on Wage and Price Stability performed cost-benefit assessments of selected proposed regulations after the agency issued them, and submitted its results as interagency comments. Thus, the Reagan process gives the OMB appreciable leverage in determining whether regulations are proposed at all. Disagreements between the OMB and agency staff over the sufficiency of a preproposal analysis can increase the costs to the agency of proceeding with the regulation, and effectively discourage or prevent further agency action.

S. 1080 would give the OMB the same power of preproposal review as it has under Executive Order 12,291, thus granting legislative approval to the executive order. The bill would go beyond the executive order by requiring that an agency make public all draft rules submitted to the OMB and explain any changes prompted by the OMB's comments.

Consider the OMB oversight reform proposal in light of the six evaluation criteria established in Part VI. First, by shifting power to the OMB, the efficiency of the proposal becoines more closely tied to the predilections of that office-and, therefore, the President-rather

105. Exec. Order No. 12,044, 3 C.F.R. 152 (1978), amended, Exec. Order No. 12,221, 3 C.F.R. 266 (1980). The Order expired on April 30, 1981.

106. Exec. Order No. 12,291, 3 C.F.R. 127 (1982). 
than to the particular agency whose goals may not coincide with presidential policy. If the OMB pursues a policy dominated by a goal of maximizing economic efficiency, any rules that survive the OMB scrutiny will more closely reflect that goal, altliough struggles between the agency and the OMB may decrease the rate of rule production or delay controversial cases. If, however, the OMB adopts a "regulatory relief" objective, seeking to avoid or rescind rules with disadvantageous distributional consequences for favored groups, then efficiency may suffer.

Second, in terms of distributional equity, prior review by the OMB favors those parties whoin the President believes deserve special protection. Because the OMB's nost effective power in the prior review process is to delay or stop regulatory initiatives, however, this process more effectively advances the interests of groups who gain from avoiding new regulations, rather than the interests of groups concerned with promoting new initiatives. Interestingly, if the OMB promotes efficiency over regulatory relief, then OMB review could deter agencies from rescinding efficient regulations, especially because the Supreme Court recently affirmed that "hard look" judicial review applies when agencies withdraw as well as promulgate a regulation. ${ }^{107}$

The extent to which OMB oversight delays proceedings and slows the agency's rate of regulation writing depends on the agency's response to the OMB's criticism and on the agency's assessment of its own regulatory agenda. On the one hand, disagreements between the $\mathrm{OMB}$ and agency staff members over the sufficiency of a preproposal analysis can make additional proceedings so costly to the agency that it may effectively be deterred from offering future rcgulatory initiatives that can be predicted to be troublesome to the OMB. Thus, OMB scrutiny may dimimisli the overall rate of agency production, or it may simply direct production into less controversial areas. On the other hand, the agency may decide to negotiate the preproposal obstacles by compiling the necessary analyses, particularly when it believes the regulations are highly justifiable. In such cases, the OMB review would add only that delay associated with the additional advance processing time between the OMB and the agency.

Analysis of our fifth criterion, the cost of participation, suggests that the incremental resources devoted by the agency to passing the OMB review would constitute the additional cost of the regulatory change. Because outside groups would, by definition, not be participat-

107. Motor Vehicle Manufacturers Ass'n v. State Farm Mutual Auto Ins. Co., 103 S. Ct. 2856, 2866 (1983). 
ing formally in this stage of the ruleinaking process, OMB review would not affect the costs to nonagency participants.

Finally, the legitimacy of the proceedings could suffer. When OMB approval occurs before public comment, the rulemaking process proceeds without eitler prior public notice or, in the case of Executive Order 12,291, but not S. 1080, a complete record of the interchanges between the agency and the OMB. ${ }^{108}$ Yet, the agency and the OMB nnay inake critical decisions at this preproposal stage. The OMB may veto regulatory options proffered by the agency, thus precluding or delaying public scrutiny of those options. Even if the OMB does not veto an option, it may still leave its imprint on the proposed rule, even though the OMB may lack the substantive expertise to frame such a rule. Although intra-agency negotiations and deliberations are inevitable and essential to government work, and although these processes invariably influence agency proposals in settings not open to formal public scrutiny, OMB review of an agency proposal that the agency considers ready for outside study could arguably be made subject to public participation without disrupting the necessary agency management functions. Seen in that light, OMB preproposal scrutiny runs counter to the trend toward increased public participation at important stages of the regulatory process, and therefore may diminish that process's legitimacy. The extent of this effect will depend, of course, on how much the lyybrid procedural reforms promote public comment. Reforms that forbid an agency from relying on data and analyses that are not accessible to public comment as part of the rulemaking file would surely promote agency legitimacy. Reforms that encourage participation by individuals not affiliated with organized interest groups are also likely to remforce public confidence in the agency.

\section{Concluding Thoughts}

Prior to June 23, 1983, rulemaking reform legislation could have provided additional levers of control over administrative discretion to all three branches of government. Througl regulatory impact analyses and the OMB's oversight, the executive branch could have influenced rulemaking decisions. The federal courts could have been charged

108. Compare Exec. Order 12,291 § 3(c)(2), 3 C.F.R. 128, 129 (1982)(OMB must pre-clear regulatory analysis, no public notice required) with $\mathrm{S}$. 1080, $\$ 3$ (amending APA to add $\S 553(f)(1)(F)-(G)$ ), 128 CONG. REC. S 2713, 2714 (daily ed. March 24, 1982) (copies of draft impact analysis submitted to $\mathrm{OMB}$, plus any changes in response to $\mathrm{OMB}$ comments, must be placed in the rulemaking record). For a discussion of the importance of differences in the timing and public disclosure of OMB review, see Viscusi, Presidential Oversight: Controlling the Regulators, 2 J. PoL'y ANALYSIS \& MGMT. 157, 159-62 (1983). 
with additional oversight through some version of the Bumpers Amendment. ${ }^{109}$ Congress also stood to gain from the pending reforms because it would have received direct review powers over specific rules through the legislative veto. Chadha has disrupted that symmetry by making the last leg of the triad untenable. Congress, which must pass any proposal to reform the APA, now appears to be the branch of government with the least to gain froin the inost frequently discussed package of reforms. Will Chadha change the dynamics of regulatory process reform by channeling Congress's energy into renewed attempts to limit agency discretion through more tightly written legislation? Or will Congress delegate more oversight responsibility to the White House and the courts? It may seem unlikely that a Congress so concerned with the Chadha shift in the balance of power would shift more power to the Presidency by enacting a bill strengthening executive oversight.

The potential effects of Chadha are not so easily predicted, however. In fact, Chadha may produce the opposite effect. As with all other participants in the rulenaking game, Congress's behavior must be assessed with reference to its own strategic interests. In 1982, the Senate unanimously approved the latest reform package, S. 1080, but the House leadership vigorously opposed it. ${ }^{110}$ The House leaders feared that the package's legislative veto provision would shift power away from the leadership toward the committees and subcommittees, who would decide whether override resolutions were introduced and passed to the floor for a vote. Furthermore, veto resolutions would crowd out other items on the House agenda, additionally complicating the leadership's efforts to control the House. Now, however, it might support a procedural reform package that does not contain a generic veto provision. Such a package offers a quick response to the problem of controlling agency discretion, which the Chadha decision has made a highly visible public issue, but would not incur opposition from mem-

109. In 1975, Senator Dale Bumpers introduced a proposed annendment to the APA that would have directed courts to decide all questions of law "de novo" and not to grant any "presumption of validity" to administrative rules. See S. 2408, 94th Cong., 1st Sess., 121 CoNo. REC. 29,956 (1975). Since that time, a variety of similar but not identical amendments generally attempting to tighten judicial review of agency actions have been called "Bumpers Amendments." See, e.g., Levin, Review of 'Jurisdictional' Issues Under the Bumpers Amendment, 1983 DUKE L.J. 355, 358-66 (1983); Lcvim, Judicial Review and the Bumpers Amendment, 1979 RECOMMENDATIONs \& Reports of the Administrative Conference of the United States 565 (1979); Pierce \& Shapiro, Political and Judicial Review of Agency Action, 59 TEx. L. Rev. 1175, 1189-95 (1981).

110. See Antitrust \& Trade Reg. Rep. (BNA), No. 1095, at 1125 (Dec. 23, 1982)(House Rules Committee blocking floor vote on regulatory reform measure); ANTITRUST \& TRADE REO. REP. (BNA), No. 1082, at 521 (Sept. 23, 1982)(Speaker O'Neill opposing H.R. 746, but working with Busmess Roundtable to draft a compromise). 
bers of the House who opposed previous attempts at generic process reform. Although the committee chairmen may be less enthusiastic about a reform package without the veto, their existing levers of power, oversight, budgeting, and government operations investigations, remam intact. Because of the constitutional nature of the bar on the veto, there is no possibility that committee chairmen could use the legislative veto as a bargaining chip, and they might see sufficient merit in the remaining proposals to proceed.

Chadha has stimulated public interest in the generic problem of controlling administrative discretion. Organized interest groups may still desire to see enacted the remaining components of the conventional package of reform measures despite the absence of the veto provision. If all of these interests converge in Congress, a procedural reform bill will have a reasonable chance of passage. On the basis of the debate to date, however, it unay pass for the wrong reason. It will pass because Congress found the veto-less generic process reform bill the only immediately available response to the public cry for a solution to the runaway agency problem. The alternative of redrafting hundreds of agency enabling statutes would take years to accomphish.

As this article explains, passage of a procedural reform bill would not be attributable to an informed conclusion that generic process reforms would solve the discretion problem. The mistaken premise that procedural reform can be evaluated solely on the basis of its ability to improve factfinding accuracy, procedural fairness, and procedural efficiency ignores the social consequences that procedural reforms can have through their influence on agency decisions. Proponents of the internal view have assumed that better procedures need only make agency actions more consistent. But in an era of substantive administrative discretion, that view is a terrible oversimphification.

This article has developed a framework for evaluating the desirability of regulatory process changes. Evaluation requires constructing a set of criteria with which to judge whether specific process changes are desirable, determining how the changes will alter the strategies of the important participants in the regulatory process, and using the criteria to assess whether the combined effects of the strategy changes will lead to preferable outcomes for society. We have suggested some ways in which different parties inay employ aspects of S. 1080, the most commonly considered generic reform, to achieve their own private goals and, im so doimg, affect the efficiency, equity, timing, rate, costs, and legitimacy of agency rules. Certainly, this effort should be extended and refined to take into account several different regulatory settings. 
Here, we have carried the exercise only far enough to raise suspicions about whether a package as complex as S. 1080 can produce universally desirable results. 